\title{
0 posmrtné historii mozku historika a politika Františka Palackého
}

\section{Petr Benda $^{1,2}$, Eliška Fulínová ${ }^{3,4}$, Vítězslav Kuželka ${ }^{5}$ \& Milena Běličová}

\author{
${ }^{1}$ Zoologické oddělení, Národní muzeum, Václavské nám. 68, 11000 Praha 1 \\ ${ }^{2}$ Katedra zoologie, Př́rodovědecká fakulta Univerzity Karlovy, Viničná 7, 12843 Praha 2 \\ ${ }^{3}$ Centrum pro teoretická studia, Jilská 1, 11000 Praha 1 \\ ${ }^{4}$ Katedra filosofie a dějin př́rodních věd, Přírodovědecká fakulta Univerzity Karlovy, \\ Viničná 7, 12843 Praha 2 \\ ${ }^{5}$ Antropologické oddělení, Národní muzeum, Václavské nám. 68, 11000 Praha 1 \\ ${ }^{6}$ Archiv Národního muzea, Na Zátorách 6, 17000 Praha 7
}

Benda P., Fulínová E., Kuželka V. \& Běličová M., 2021: On the posthumous history of the brain of historian and politician František Palacký. - Journal of the National Museum (Prague), Natural History Series 190: 5-44.

\begin{abstract}
Abstrakt: Historik a politik František Palacký (1798-1876) byl jednou z nejvýznamnějších osobností kulturního a politického pohybu střední Evropy 19. století; když roku 1876 v Praze zemřel, stal se jeho pohřeb významnou událostí celé české společnosti. Ovšem ještě před pohřbem, 30. května večer, byl z Palackého hlavy vyňat mozek, který byl jako tekutinový preparát zachován a uložen v Museu království Českého (dnešním Národním museu) v Praze. V současné době je tento preparát uložen ve válcové skleněné nádobě vložené do dřevěné skříňky a ukryté ve výklenku stěny sloupu v Pantheonu v prvním patře historické budovy Národního musea. Pátrání v Archivu Národního musea přineslo několik dokumentů, které přiblížily některé úseky historie preparátu Palackého mozku, i když jeho osud v dalších obdobích stále zůstává nejasný. Preparát mozku zůstal několik let uložen v knihovně musea a někdy v letech 1878-1899 (velmi pravděpodobně nejpozději roku 1892) byl přesunut do zoologických sbírek Musea, kde zůstal až do roku 1931. Nejistá je však následná historie mozku až do roku 1958, kdy byl instalován do výklenku sloupu v Pantheonu, kde zůstává dodnes (s přerušením posledních pěti let), ale opět v gesci nejprve zoologického oddělení a od roku 1967 anthropologického oddělení.
\end{abstract}

\begin{abstract}
František Palacký (1798-1876), a historian and politician, was one of the most eminent personalities of the Czech society of the 19th century. He died on 26 May 1876 in Prague and on 30 May 1876, in the evening before the burial, the Palacký's head was dissected and his brain was extracted and preserved as a liquid preparation. Then, it was deposited in the Museum of the Kingdom of Bohemia (present National Museum) in Prague; currently it is stored in a jar concealed in a wall niche of a column (next to a large statue of Palacký) in the Pantheon hall of the historical building of the National Museum on the Wenceslaus square in Prague. The investigation of the Museum archive brought some documents which elucidate certain parts of the history of the Palacký's brain preparation, although its whereabouts during other periods still remain hidden. For several years after its extraction, the Palacký's brain was deposited in the Museum library, and between the years 1878-1899 (most probably in 1892 at the latest), it was handed over to the Department of Zoology of the Museum, where it remained until 1931. Next fate of the brain is uncertain until 1958, when it was installed in the wall niche in the Pantheon hall, where it remains till now (with an interruption in the last five years), but again under the responsibility of the Department of Zoology and Department of Anthropology, respectively.
\end{abstract}

Klíčová slova: historie sbírek, přírodovědecké sbírky, Národní muzeum (Praha)

Key words: History of collections, natural history collections, National Museum (Prague)

Received: 17 November 2020 | Accepted: 14 January 2021 | Published on-line: 28 April 2021 


\section{Úvod}

František Palacký (1798-1876), historik, spisovatel a politik, je považován za jednu z nejvýznamnějších a nejvlivnějších postav české společnosti 19. století a jejího národního uvědomění a emancipace. Jak jeho odborný význam historika, tak zejména jeho autorita politika, zakladatele a prvního vůdce Národní strany (později zvané staročeská) vysloužila Palackému už během jeho života označení Otec národa. Tento titul zůstává synonymem jeho jména dodnes; ovšem několik posledních desítek let habsburské vlády nad českými zeměmi měl navíc i určitou mythologickou funkci: personifikoval symbol národní sounáležitosti české společnosti (Štaif 2009). V této posici byl Palacký nahrazen až více než 40 let po smrti (a jen díky vzniku Československé republiky) presidentem Osvoboditelem, resp. tatíčkem (Tomášem Garrigue) Masarykem. Ovšem výjimečný význam Palackého jako historika a politika je uznáván dodnes, obě tyto polohy jeho osobnosti se spojují např. v dedikaci knihy o prvopočátcích českého státu s podtitulem Vstup Čechů do Dějin od dalšího výrazného historika, Dušana Třeštíka, již věnoval "Památce Františka Palackého, největšího z českých historiků, který vymyslel tento národ" (Třeštík 1997). Národem se tu zjevně nemíní pouze entita, o níž píše a jejíž význam zdůrazňuje historik, ale i skupina, již vytváří a ovlivňuje politik. V případě Palackého tedy nikdo menší než Otec národa.

František Palacký se narodil 14. června 1798 v Hodslavicích na severovýchodní Moravě, od roku 1823 až do své smrti žil a pracoval v Praze. Palacký zemřel v pátek 26. května 1876 v půl čtvrté odpoledne ve společnosti své dcery a zetě, Marie Riegrové a Františka Ladislava Riegera, s nimiž obýval byt v prvním patř̌e MacNevenova domu v Pasírské (dnes Palackého) ulici čp. 719/7 na Novém Městě pražském. 0 posledních hodinách života Františka Palackého, stejně jako o úkonech s jeho tělem v hodinách po smrti podala svědectví ve svých osobních zápiscích Palackého vnučka Marie Červinková-Riegrová. Výňatky z těchto zápisků byly posmrtně publikovány ve sborníku k 100. výročí narození Palackého (Červinková-Riegrová 1898); ovšem Červinková-Riegrová nebyla sama př́tomna událostem, jejich popis zaznamenala podle zpráv své matky a dalších př́ibuzných až v době krátce po pohřbu Palackého. Popis osudu Palackého těla od smrti až do uložení do země v hrobce na hřbitově v Lobkovicích (dnes součást Neratovic), kde Palačtí vlastnili velkostatek, je na místě zde popsat úplněji, vzhledem k později diskutovaným thematům.

V den smrti rodina tělo Palackého pouze převlékla a položila na umrlčí prkno, pak se s ním loučili nejbližší, dcera Marie strávila u těla celou noc. Úkony následující a některé své pocity popisuje Marie Červinková-Riegrová (1898: 176) takto: "Druhého dne [po smrti], 27. května v sobotu, [...] přišel ráno fotograf, a nebyl ještě hotov, když již naň čekal sochař Myslbek, který vzal sádrový odlitek obličeje, a jak jsem slyšela, též ruky jeho pravé, přišel prý k němu kdosi, žádaje ho naléhavě o odlitek ruky, jež psala historii českou. Po Myslbekovi přišel opět jiný fotograf, a odpoledne neb o polednách vzali si již lékaři mrtvolu dědečkovu do druhého poschodí k balsamování. Balsamování trvalo až do půlnoci; proto jsme dědečka viděli až v neděli ráno. Lékaři nalezli jen jeden cípek plic zanícený, ale vodu v nohou, těle a plicích; smrt nastala oedemem plic a vůbec marasmem. [...] Později [= 30. června] vyňali dědečkovi mozek a dali ho do líhu pro museum. Je prý to zvláštnost vědecky znamenitá, mozek neobyčejně velký, neobyčejně vyvinutý, a zvláště znamenitý, skoro bezpř́kladný jest úkaz, že v tak vysokém stáří nacházel se mozek v úplném vývinu. Líto mi bylo, že s dědečkovou mrtvolou tak zacházeli, jako by jim náležela."

Odpovědnost za veškeré činnosti spojené s pohřbem a ostatními akty rozloučení s Františkem Palackým vzala na sebe pražská městská rada, která již několik minut po oznámení úmrtí 26. května odpoledne "ukončila své sezení a uzavřela se starati o pohřeb" (Červinková-Riegrová 1898: 175). Zpravodaj listu Světozor o událostech v celkem úsporné reportáži zpravil následovně (Anonymus 1876a: 329): “V sobotu večer byla mrtvola Palackého pytvána a balsamována od okresních lékařů pp. drů. Steffala a Prokše, což vyžadovalo času několik hodin. Shledáno, že smrt nastoupila následkem ochrnutí plic. Na to byla mrtvola ob- 


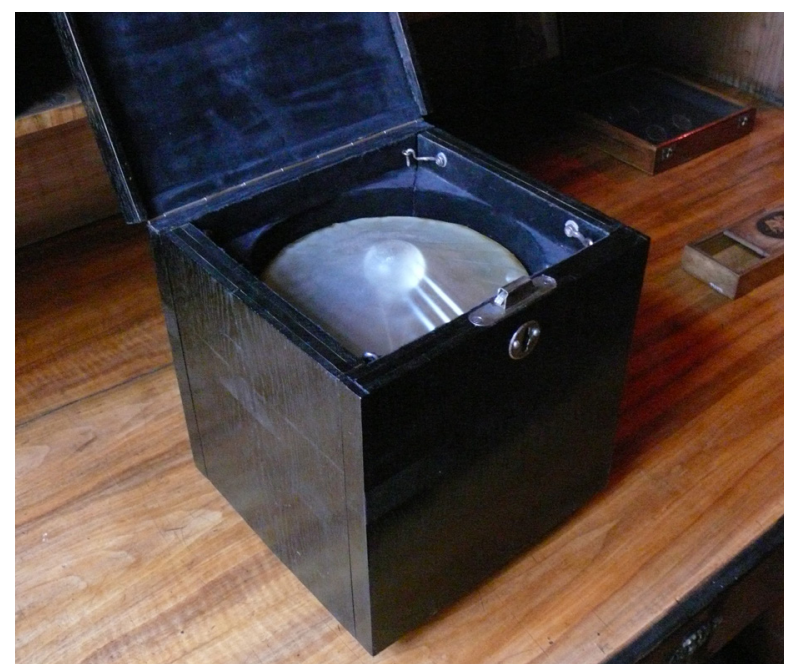

Obr. 1. Dřevěná a sametem vyložená rozkládací skříňka s nádobou obsahující preparát mozku Františka Palackého; skříňka má jen zvednuté víko, boční stěny Ize odklopit do stran po odjištění háčků viditelných v rozích skříňky. Foto: $P$. Benda. lečena v černý šat, a připnuty mu veškeré řády, [...]. Konečně mrtvola uložena byla do skvostné dvojité rakve, a postavena na prozatimní katafalk, okolo něhož pak rozžato několik voskových svící. // $\mathrm{V}$ neděli ráno před sedmou hodinou dostavili se do domu zemřelého někteří radové městští, členové 'Českého klubu', měštanské besedy a hodnostáři téměř veškerých národních spolků pražských. Superindendent [evangelické církve augšpurského vyznání] p. Molnár vykonal nad rakví modlitby a měl krátkou avšak dojemnou řeč, $\mathrm{v}$ níž poukázal na zásluhy zesnulého. Po vykonání církevních obřadů loučila se rodina zesnulého s drahým nebožtíkem. Jeden

po druhém přiblížili se k rakvi a líbajíce ruce nebožtíkovy, křížem přes prsa složené, rozloučili se s ním na vždy. Na to byla rakev zavřena a snešena od zrrízenců pohřebínho ústavu do průjezdu domu, kdež mezi tím shromáždili se členové 'Českého klubu', několik čet 'Sokola' a členové akademického čtenářského spolku v černém obleku. Členové ‘Českého klubu' rakev vyzvedli na ramena, aby ji donesli do staroměstské radnice. [...] V průjezdu radnice očekávalo mrtvolu několik městských radních, kteří přijavše ji, s odkrytými hlavami vstoupili v čelo průvodu a ubírali se do druhého poschodí, kdež mrtvola měla být slavnostně vystavena. // [...] drahá mrtvola střežena byla čestnou stráží, skládající se z členů pražského 'Sokola,' sborů městské pěchoty a granátníků jakož i akademiků v starodávném kroji a že nával obecenstva po všechen čas vystavení mrtvoly byl ohromný."

Balsamované tělo Františka Palackého bylo pak tři dny, od 14 hodin v neděli 28. června do 18 hodin v úterý 30 . června vystaveno v druhém poschodí Staroměstské radnice. Světozor k tomu doplňuje (Anonymus 1876b: 342): “Obličej nebožtíka byl téměř nezměněný; odpočíval v rakvi jako by dřímal. Za hlavou zesnulého stál velký stř́íbrný krucifix a několik palem. [...] Kolem katafalku hořelo na stříbrných vysokých svícnech 80 velkých svící, které zvláště k tomu účelu byly ulity z nejčistšího vosku, aby nevydávaly mnoho dusivého kouře. // [...] Po celý čas výstavní byl nával obecenstva ohromný; nepřetržitou řadou ubírali se kolem mrtvoly ctitelé zvěčnělého a předce pro neustálý nával obecenstva pražského a okolního nebylo mnohým popřáno rozloučit se naposledy s otcem milovaným."

Večer 30. května po uzavření síně Staroměstské radnice dostavil se k Palackého tělu městský lékař Šteffal, aby otevřel lebku a odebral a uchoval Palackého mozek. Ve středu 31. května ráno byla rakev uzavřena skleněným víkem, které bylo přiletováno, a ještě krátce bylo umožněno rozloučení pozůstalým, kteří neměli dosud možnost Palackého po smrti vidět - mezi nimi i Palackého vnučce Marii Červinkové-Riegrové s rodinou (viz poznámka na str. 27). Po vykonání pohřebních obřadů bylo přišroubováno kovové víko vnitřní rakve a ta byla připravena $\mathrm{k}$ pohřbu.

Popis pohřbu přineslo více listů, Národní Listy a Politik obšírně referovaly rozsáhlými texty, včetně přepisů smutečních proslovů a soupisů účastníků. 0 den později vyšel spíše stř́́dmý text ve Světozoru a krátký referát v Bohemii. Národní Listy odhadují počet účastníků po- 


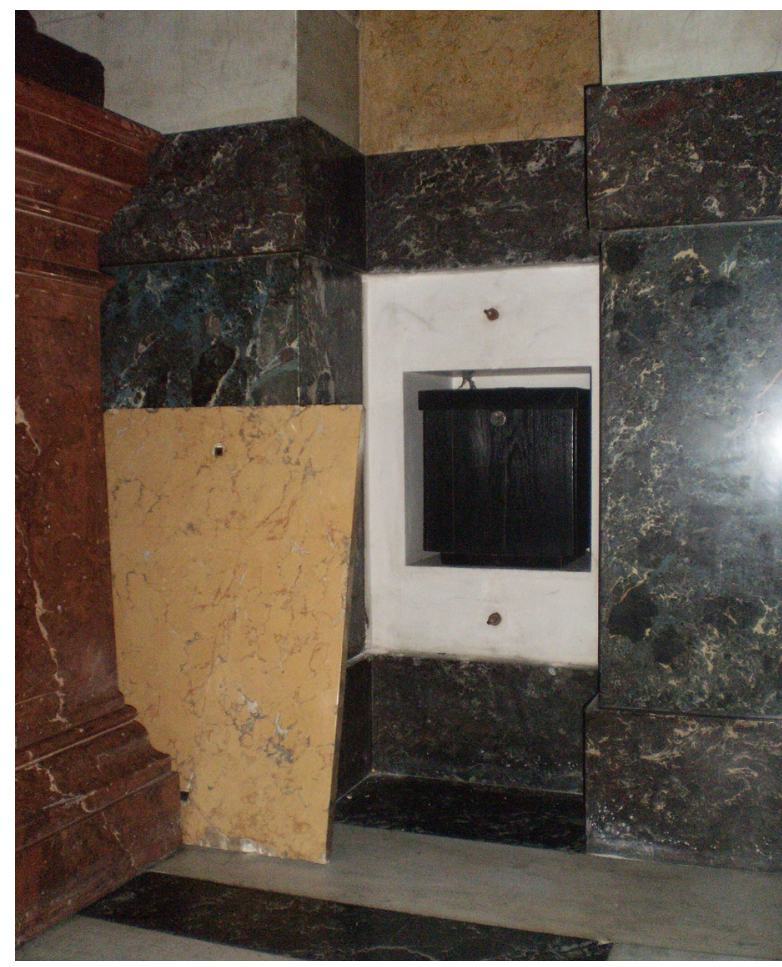

Obr. 2. Otevřený výklenek ve stěně severního sloupu Pantheonu v prvním patře hlavní/historické budovy Národního musea na Václavském náměstí sloužící k trvalému uložení skříňky s nádobou obsahující preparát mozku Františka Palackého; nalevo od výklenku opřen kryt s barevným motivem napodobujícím umělý kámen, jímž je sloup obložen. Foto: V. Kuželka. hřebního průvodu na 30.000 a pasívních účastníků pohřbu $\mathrm{z}$ řad publika na 100.000 osob (Anonymus 1876c). Světozor pojímá odhad účasti $\mathrm{v}$ průvodu ještě znamenitěji a popisuje pohřeb následovně (Anonymus 1876d: 329-330): "Pohřeb Palackého byl tak velkolepý, že podobného Praha dosud neviděla a sotva brzy uvidí. // Před desátou hodinou [31. května] byly sín smuteční na staroměstské radnici a sousední kanceláře presidiální přeplněny hostmi, mezi nimiž pozorovati bylo zástupce místodržitelství [...]. Dále zde byli deputace přečetných měst, obcí a okresních zastupitelstev, university, techniky, kr. české společnosti nauk, středních škol, komory advokátní i notářské, výbor Musea a 'Svatoboru,' [...]. Obecnou pozornost vzbudil též stařičký děkan Marek z Libuně, jenž navzdor tížící starobě $\mathrm{k}$ rakvi zemřelého se dostavil a ji až do Karlína doprovodil ${ }^{1}$. // Přehojné bylo účastenství duchovenstva katolického, ačkoliv Palacký byl protestan-

tem. Evangelických duchovních obojího vyznání dostavilo se celkem 14, kromě toho pak dva kněží církve pravoslavné. // V deset hodin vstoupil do síně superintendent pan Dan. Molnár, a prosloviv krátkou řeč, mrtvole požehnání udělil. Před obřadem i po obřadu zapěl 'Hlahol' dojemné sbory smuteční. Po té rakev uzavřena a nešena do průjezdu radnice a postavena po pohřební vůz. [...] // Průvod sám byl velkolepý; súčastnilo se ho aspoň 50.000 osob, cesta pak, kudy se průvod ubíral [...], vroubena byla s obou stran davy obecenstva jak pražského tak i přespolního. [...] // Ačkoliv průvod kráčel šestistupem a to krokem dosti rychlým, přece trvalo půl druhé hodiny, než přešel kolem diváka. Praporů napočteno půl třetího sta [...]. // Když o 1 hod. pohřební vůz přijel na začátek Karlína, počala se na Žižkově střelba z hmoždírů. V Karlíně v sadech Jungmannových zřízen byl vkusný černý katafalk a zde pohřební průvod stanul, aby mohl býti fotografován. // [...] K pohřebnímu vozu [v Karlíně] zapřaženi čtyři čerství koně a průvod v čele maje dlouhé řady statečných banderistů a skládaje se z nekonečné řady povozův soukromých i najatých (počtem asi 300) hnul se dále k poslednímu cíli - k Lobkovicům. // Kudy jel pohřební průvod, všude osady byly v smuteční roucho zahaleny, všude tisícové lidí loučily se s nebožtíkem, všude ozýval se hlahol zvonů a střelba z hmoždírů. // Když průvod přiblížil se Lobkovicům, veledůstojný superintendent D. Molnár vyšel mu vstříc s evangelickým duchovenstvem a rakev doprovázel k připravené hrobce, kde milostivá

1 Děkan Antonín Marek, současník a spolupracovník Josefa Jungmanna, byl v té době 91 let stár. Působil dlouhá léta v Libuni v severovýchodních Čechách, roku 1876 ale už dožíval v Praze; Palackého přežil o rok. 
chot' Palackého již po 16 let odpočívala. // Zapěl 'Hlahol’ a farář p. Nykles jménem obce pražské mrtvolu odevzdávaje obci lobkovické, žádal, aby hrob, všemu národu posvátný, bedlivě ošetřovali a chránili. Pak evang. farář p. Felix Molnár dojemnou řečí loučil se s nebožtíkem a modlil se nad hrobem. // Pomocí 'Sokolů' snesla se těžká rakev do hrobky a z přivežených věnců nakupena nad ní mohyla. [...] // Evang. senior p. Lány děkoval ještě přítomným za účastenství a za truchlivého pění 'Miserere' zavřela se hrobka o 7. hodině večerní." Denní tisk pak několik dní přinášel zprávy o mších na Palackého počest konaných v mnoha místech, nejen v Čechách či Rakousku, ale i v zahraničí, zejména ve slovanských zemích.

Zevrubný a pietní popis pohřebního průvodu publikovaný Světozorem celkem pochopitelně pomíjí zajímavý jev, který zaznamenala ve svých zápiscích Marie Červinková-Riegrová a který není nepodstatný po pochopení toho, jak dobová veřejnost vnímala osobnost Františka Palackého. Ze zápisků Palackého vnučky shrnul historik Jiř́i Štaif chování publika na pohřbu následovně (Štaif 2009: 293): “Cesta od Staroměstské radnice na lobkovický hřbitov trvala v parném počasí s přestávkami a vynucenými zastávkami od tři čtvrtě na jedenáct do šesti hodin odpoledne. Pohřební vůz měl totiž po cestě několik nehod, jež využívali přihlížející k tomu, aby si ze smutečních věnců něco utrhli na památku na tak slavný den, což Riegerovu rodinu velmi zaskočilo. $\mathrm{K}$ ještě trapnější scéně došlo na poměrně stísněném lobkovickém hřbitově, kde se před spuštěním rakve do hrobu přítomní muži a ženy vrhli na věnce, stuhy a květiny. Snaha získat při této př́ležitosti nějakou tu 'relikvii' byla tak úporná, že neměla daleko k davové hysterii. Obřad musel být proto přerušen, aby tak byla poněkud ztlumena neočekávaná 'pranice a mačkanice'.' O cupování smutečních věnců Světozor či Národní Listy nepodávají zmínek, ovšem poslední list uvedl počet věnců na smutečním voze, kterých však vůbec nebylo mnoho (Anonymus 1876c: 1): "Na voze nemělo býti podle usnešení soukromých věnců, jen věnec rodiny a obce pražské měly vůz krášliti. Zatím zavěšen na vůz ještě nádherný věnec prince Hanavského a věnec na jehož bílé pentli čtlo se v modrých literách: 'Skrejšovský svému zastánci'.' Pokud se tedy postupné davové cupování týkalo jen čtyř věnců na cestě dlouhé třicet kilometrů, nemohlo to nemít na důstojnost vlastního pohřebního obřadu vliv. To, že se tomuto rozebírání smutečních věnců novinové zprávy vůbec nevěnují (stejně jako např. nehodám po cestě), lze považovat za známku toho, že jej v dané situaci považovaly za nepatřičné, a že tedy bylo patrně v dané době tak jako dnes neobvyklé a vnímané jako k Otci národa neuctivé.

Dobové zprávy o smrti, př́pravách na pohřeb a o pohřbu Františka Palackého se zmiňují podrobně o manipulacích s tělem zemřelého, včetně balsamace těla, pitvy hlavy, vynětí mozku a jeho konservaci. Jak zaznamenala vnučka Palackého ve svých zápiscích, mozek byl uložen v lihu a určen pro museum, myšleno Museum království Českého v Praze, současné Národní museum. Účel zachování preparovaného mozku nebyl ovšem zřejmý (Národní Listy píší v souvislosti s ním o "věčné památce" a jiný důvod veřejně presentován nebyl; viz níže) a ani rozhodování o tomto úkonu není z dobových pra-

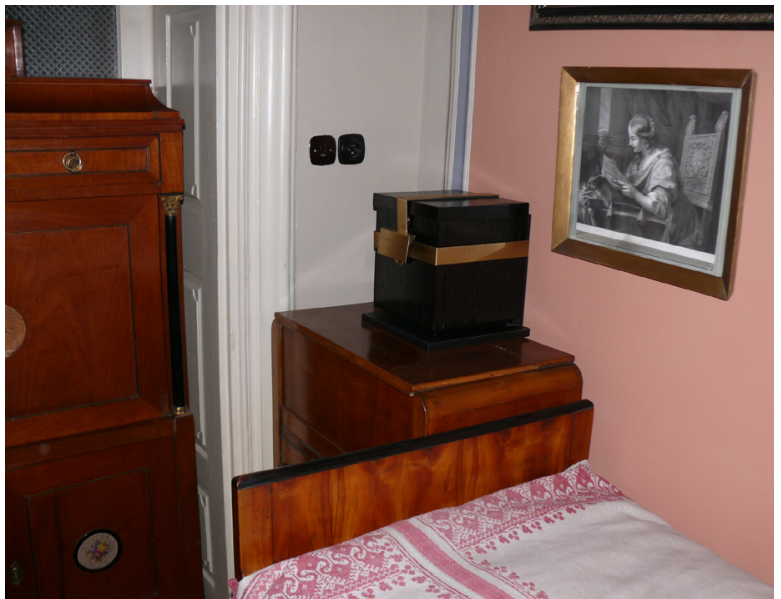

Obr. 3. Dočasné uložení skříňky s preparátem mozku Františka Palackého na nočním stolku u Palackého umrlčího lůžka v bývalém Palackého bytě, dnes Památníku Františka Palackého a Františka Ladislava Riegera v Palackého ulici na Novém Městě pražském. Foto: P. Benda. 
menů zřejmé. Podle Štaifa (2009) nesly Palackého dcera a vnučka s jistou nelibostí, že byl Palackému vyjmut mozek. To ostatně sama Marie Červinková-Riegrová jemně naznačuje v popisu dějů po Palackého smrti (viz výše). Ovšem žádné známé prameny neupřesňují, kdo a jakou procedurou o vynětí a zachování mozku rozhodl - jako nejpravděpodobnější se zdá, že o tom rozhodla pražská městská rada, či osobně v té době zastupující náměstek pražského starosty (purkmistra) Antonín Otakar Zeithammer. Ten byl jako jediný (kromě lékaře) přítomen pitvě Palackého hlavy večer před pohřbem, a stejně tak vedl deputaci městské rady k městskému lékaři Šteffalovi. Možná se jednalo o nápad V. Šteffala, který pro něj městskou radu či A. O. Zeithammera přesvědčil, nebot' chtěl mozek Otce národa sám zkoumat, jak ostatně i později napsal (Šteffal 1877). Podle toho, jak Marie Červinková-Riegrová popsala Myslbekovo odlévání Palackého ruky (viz výše), podobné záležitosti zjevně mohly být řešeny ad hoc, na základě pouhého projevu zájmu. Každopádně se vůbec nezdá být zjevné, že by do rozhodování byla zapojena rodina Palackého. Její ženská část naopak situaci nesla $\mathrm{s}$ (pochopitelnou) nevolí, kterou ale v daném společenském prostředí - kde si nějaký vztah k Palackému nárokovalo množství osob z nejrůznějších segmentů tehdejší společnosti - asi př́liš rasantně nepresentovala.

Preparát mozku Františka Palackého skutečně skončil v Museu království Českého, dnešním Národním museu, jak bylo od začátku deklarováno. V museu zůstal až do současnosti a jeho stav je pravděpodobně velmi podobný tomu, jaký byl už v roce 1876. Je umístěn ve skleněné nádobě, ponořen ve fixační tekutině a položen na vrstvu vaty, nádoba je svrchu přetažena plastovou folií (nahrazující původní měchuřinu) a uzavřena v dřevěné skř́ńnce (obr. 1). V posledních létech byl preparát skryt návštěvníkům musea a umístěn v malém neoznačeném výklenku stěny severního sloupu Pantheonu v prvním patře dnešní hlavní či historické budovy Národního musea na Václavském náměstí (obr. 2). Nyní (od roku 2015) je přechodně uložen v bývalém Palackého pražském bytě, dnes Památníku Františka Palackého a Františka Ladislava Riegera v Palackého ulici na Novém Městě, na nočním stolku v hlavě postele, na níž František Palacký zemřel (obr. 3).

Přestože je preparát mozku Františka Palackého trvale uložen v Národním museu (resp. Museu království Českého) prokazatelně déle než 140 let, jeho historie není přímočará. Vzhledem k jeho jedinečnosti nebylo s tímto preparátem nakládáno jako s běžnou částí musejní sbírky, alespoň po většinu doby. Historii tohoto preparátu a nakládání s ním je proto zajímavé připomenout, o což se snažíme v odstavcích níže. Pro snazší orientaci v posmrtných dějinách Palackého mozku jsou všechny známé archivní dokumenty týkající se preparátu doslovně uvedeny v chronologickém pořadí v Appendixu 1 a všechny osoby, které jsou v textu zmíněny, jsou jednoduše připomenuty v glosáři v Appendixu 2.

\section{Historie preparátu}

Celou historii preparátu mozku Františka Palackého zrekonstruovat prozatím nelze, ovšem její podstatné milníky, či alespoň jejich většinu, lze odtušit z údajů publikovaných či doložených jinými prameny. $\mathrm{V}$ následujícím textu jsou citace archivních pramenů uváděny podle signatury Registratury Národního musea (RNM) vedené Archivem Národního musea; v textu jsou čísla uváděna pouze se signaturou bez čísel kartonů, stejně tak u legend obrázků (pro úplnou informaci viz Appendix 1). Dva dokumenty jsou bez archivní signatury (BAS).

Dlužno uvést, že publikací zmiňujících Palackého mozek je velmi málo a všechny se týkají období bezprostředně po smrti Františka Palackého (pomineme-li publikační rozruch způsobený převozem preparátu mozku mezi částmi Národního musea v roce 2015). 0 samotném odebrání mozku byla vydána krátká, ale podrobná zpráva v Národních Listech v pátek 2. června 1876 (tj. dva dny po pohřbu a den po reportážích o pohřbu v témže periodiku), tedy až tři dny po vyjmutí mozku (Anonymus 1876e: 3): "Hlava dra. Frant. Palackého byla pytvána. $V$ úterý večer [ $=30$. května 1876], kdy již obecenstvu nebyl k vystavené mrtvole v staroměstské radnici přístup dovolen, povolán dr. Steffal, aby pytval hlavu zesnulého. Nikdo kromě ná- 
městka p. 0. Zeithammera nebyl prrítomen. Dr. Steffal konstatoval, že lebka jest nadobyčejně krásně tvořena, mozku mnoho a týž také velmi pěkný. Mozek byl z hlavy vyňat a ve zvláštní skleněné nádobě uschován, která má býti na věčnou památku v českém museum uložena. Teprvé po vykonaném tomto pytvání byla vnitřní rakev zaletována, vrchním kovovým víkem přikryta a na zámek uzavřena.” Týž den, v pátek 2. června, vyšla také krátká zpráva v Bohemii (Anonymus 1876f: 5): "Palackýs Kopf ist am Dienstag, bevor der Sarg verlöthet wurde, von Dr. Steffal untersucht worden. Hie[r]bei stellte sich heraus, daß die Hirnschale ungewöhnlich hübsch geformt und das Gehirn schön und in großer Menge vorhanden war. Das Gehirn wurde in ein gläsernes Gefäß gethan und dieses versiegelt; wie der 'Pokr.' bemerkt, wird dasselbe ohne Zweifel im böhmischen Museum aufbewahrt werden." Velmi podobný text jako v Národních Listech, jen o něco stručnější, byl publikován 6. června ve Světozoru jako odstavec v rámci zprávy o vystavení Palackého těla ve Staroměstské radnici ve dnech před pohřbem (Anonymus 1876b).

U výročí jednoho roku od úmrtí Františka Palackého vydal Václav Šteffal, jako oslavnou připomínku Otce národa, popis výsledku pitvy (spíše však podrobnějšího ohledání) jeho těla v Časopise Lékařrũv Českých, včetně popisu vnějšího zkoumání hlavy a krátkého popisu mozku Palackého (Šteffal 1877: 169-170): "Hned po konstatované smrti Palackého odebrala se deputace slavné rady města Prahy, majíc v čele pana 0 . Zeithammera, náměstka purkmistrova, k panu profesorovi dru. Weissovi s prosbou, aby vykonal balsamování mrtvoly. Pan profesor odkázal deputaci ke mně. Budiž mně proto i na tomto místě dovoleno, abych jak slavné radě král. hlavn. města Prahy tak panu prof. Weissovi za tento tak čestný a vznešený úkol co nejvřeleji poděkovati směl. Kéž by tělo Palackého tak věkům vzdorovalo, jako že jim duch jeho vzdorovati bude! // I my lékařové nesmíme připustiti, aby nás památný výroční den úmrtí Palackého beze známky zevnější minul. // Nebude snad proto od místa, podám-li krátce výsledek ovšem neúplného pitvání vzácné mrtvoly. // [...] Délka zcela rovně ležícího těla od temene hlavy až po paty byla 182 centimetry, tedy bezmála sáh. Avšak i pro tak vysoké tělo byly rozměry hlavy přes obyčejný poměr veliké. Jak mě pan dr. Rieger zdělil, byly klobouky ve skladech vždy Palackému malé; jeho kloboučník měl pro něj zvláštní formu. Přímý průměr hlavy od těla [= čela] k týlu (glabella - protuberantia occipitalis externa) 20 centimetrů. Největší příční průměr (sutura coronalis) $13 \cdot 1$ centimetrů. Kolmý průměr od předního konce švu šípového k bradě $24 \cdot 1$ centimetrů. Objem hlavy k př́mému průměru 60 centimetrů. // Navzdor těmto nad obyčej velkým rozměrům neměla hlava pražádného pathologického rázu. Počítáme-li podle Henleho, jehož udání o průměrech hlavy považuji za pravdě nejbližší, nejobyčejnější poměr přímého průměru hlavy k největšímu příčnímu průměru jako 17:14 (coëfic. asi 1.21) a provnáme-li s tímto poměrem poměr těchže průměrů na hlavě Palackého 20:17 (coëf. 1·17 asi); tu vidíme, že př́́slušný objem hlavy u Palackého jest bližší kruhu, než obyčejně bývá. Hlava Palackého má tedy více ráz brachykephalický - krátkohlavý. Známo jest, že švédský anatom Retzius počítá Slovany ku orthognatickým, kolmoobličejovým brachykephalům. // [...] // Podání přesného úsudku o orgánech vnitřních při mrtvolách k balsamování určených jest velmi obtížné. Před vstřikováním tepen tekutinami žíravými nemohou se ústroje z dutin těla vyndati; a po vstř́iknutí promění se jejich barva, váha, konsistence atd. [...] // Lebka byla teprv čtvrtý den po smrti otevřena, když byla mrtvola den před pohřbem s katafalku sejmuta, aby se rakev mohla zaletovati. Hlava, kterou kryla známá vlásenka, jest skoro úplně prosta vlasů. Kůže se na průřezu ukázala jak obyčejně něco tenší, než bývá kůže hlavy bujnými vlasy pokrytá, a následkem injekce docela suchá; ani kapky krve se neobjevilo. Kosti lebky nepř́liš silné, diploe sporá, švy z většího dílu srostlé. Mozek podle udaných průměrů hlavy nad obyčej veliký, ztuhlý tak, že z lebky vyndán, skoro pranic nesplaskl. Závitky drobné, husté; brázdy úzké, hluboké. Ze strany něco pootevřená dutina mozková neukázala se býti zvětšená. Vážení mozku nebylo by mělo pro vstřiknutou tekutinu rtutovou žádnou cenu. Podle mozku by nebyl nikdo na vysoké stáŕí zemřelého soudil. Mozek byl pod dozorem pana bibliotékáře Vrtátka do museum království českého uložen, jsa ponořen v silném roztoku sublimatovém. Rád bych se pustil do podrobného rozboru látky mozkové, což by ovšem 
Inved po pohibu zensucho hisoriografa pana gro frandiscen Calarne'to byl mozes slavneho nience fohoto $v$ lihu Musea

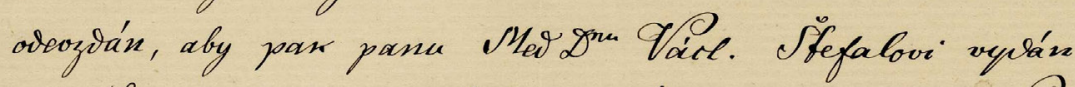

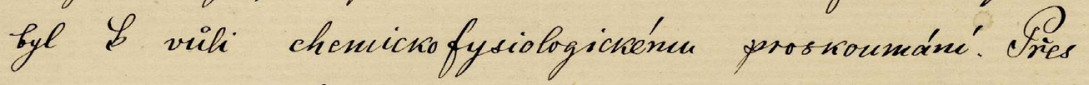
vierso priponinámé gistala vic Lalo posui nevyrizena, a dolyiny' preparat muté de pro nedostater prihorného mista

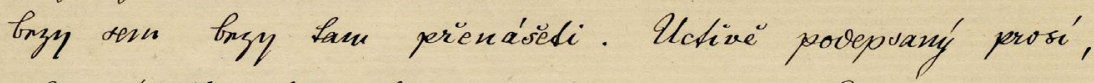
aby galejisos Sato las nob onows koneine tyla vyrizena.

90 raze due 10 peros. 2828.

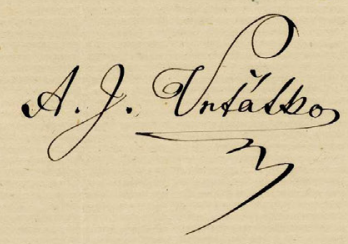

Obr. 4. Dopis bibliothekáře Musea království Českého Antonína Jaroslava Vrtátka z konce roku 1878 ohledně rádného umístění preparátu Palackého mozku ve sbírkách musea (RNM 1878/b. č.). Scan: M. Běličová. 
delší, nepřerušovaný klidný čas vyžadovalo. V tom mě bránějí smutné všeobecné zdravotní poměry nynější, poněkud i vlastní choré oči. Avšak i makroskopicky shoduje se krásný ten mozek s krásným duchem Palackého, jak dalece si smíme podle stávajících vědeckých pozorování tento závěrek dovoliti."

Kromě konkrétních údajů o tělesném stavu Františka Palackého (a zajímavé ukázky dobové představy o tehdy podstatných faktech) a poněkud paradoxní skutečnosti, že první výročí smrti uznávané osobnosti bylo oslaveno popisem fysického stavu jeho těla a různých vnitřních orgánů, přináší Šteffalův text několik dalších údajů o nakládání s mozkem Palackého. Předně je zde zmíněno balsamování těla Palackého druhý den po smrti, jež zřejmě proběhlo roztokem chloridu rtut'natého (sublimatu), velmi silného činidla užívaného ke konservaci či desinfekci. Díky němu bylo tělo uchráněno před účinky rozkladu během tří dní, kdy bylo exponováno truchlení veřejnosti a než bylo umístěno v rakvi pod přiletovaným víkem. K celkovému ohledání a pitvě, jakož i balsamaci došlo den po smrti, 27. května odpoledne a večer, za účasti okresních lékařu Václava Šteffala a Josefa Prokeše (Anonymus 1876a), zatímco pitva hlavy proběhla až 30. května (Anonymus 1876b, e). Zdroje shodně uvádějí, že k pitvě hlavy došlo až před uložením těla do rakve, kdy byl také vyjmutý mozek uložen do nádoby se sublimatovým roztokem, není však jasné, zda v alkoholu či ve vodě. Vodným roztokem sublimatu byla patrně provedena balsamace, resp. konservace mrtvého těla, ovšem uložení mozku pravděpodobněji proběhlo do roztoku lihového, jednak vzhledem k požadavku dlouhodobého uchování a jednak se sublimat v lihu lépe rozpouští.

Zajímavé je svědectví Šteffala, tehdy městského okresního lékaře v Praze, že balsamování těla Palackého odmítl Vilém Weiss a poukázal s touto činností deputaci městské rady na Šteffala. Weiss byl tehdy docent lékařské fakulty pražské university a pozdější řádný profesor a první děkan české lékařské fakulty nově rozdělené Karlo-Ferdinandovy university (Šteffal o něm píše jako o profesoru, nebot' v roce 1877 byl již mimořádným profesorem). Jakožto náležitá veličina se rok předtím podílel na balsamaci těla císaře Ferdinanda I., takže byl nepochybně kvalifikován i k balsamaci těla Otce národa. Zdá se také, že národní či politická gloriola Palackého nemusela být pro Weisse překážkou - navzdory německému př́ímení mu bylo vlastní české národovecké cítění, mj. se podílel na tvorbě českého lékařského pojmosloví. Tato okolnost tedy zůstane prozatím nevysvětlena; ostatně třeba byl jen Weiss v danou chvíli zaneprázdněn jinou naléhavou činností.

Šteffal (1877) však především potvrzuje, že Palackého "mozek byl pod dozorem pana bibliotékáře Vrtátka do museum království českého uložen" patrně krátce po jeho umístění do zmíněné nádoby s roztokem sublimatu. Jelikož samotnému vyjmutí mozku byl svědkem pouze Antonín Otakar Zeithammer z moci své funkce náměstka purkmistra hlavního města Prahy (přítomen byl nepochybně proto, že v té době Praha neměla purkmistra - předcházející Josef Huleš odstoupil těsně před pohřbem v květnu 1876 a nový, Emilián Skramlík, byl zvolen až 12. června), samotné předání bibliothekářovi Musea království Českého, Antonínu Jaroslavu Vrtátkovi, proběhlo až o něco později, patrně po Palackého pohřbu, když byl preparát technicky dokončen. Po necelém roce je ovšem konstatováno Šteffalem (1877), že preparát je v museu, a po dalším roce a půl (10. prosince 1878) píše sám Vrtátko (RNM 1878/b. č.; obr. 4), že "hned po pohřbu zemského historiografa pana Dra Františka Palackého byl mozek slavného učence tohoto v lihu Museu odevzdán, aby pak panu Med Dru Václ. Štefalovi vydán byl kvůli chemickofysiologickému proskoumání". K tomuto předání zpátky Šteffalovi však nepochybně nikdy nedošlo, jak nasvědčují další známé segmenty z historie preparátu mozku a jeho současný stav (viz níže). Především však Vrtátko konstatuje, že nebyl preparát mozku přidělen žádné části musea a stále setrvává v knihovně, a že dosud není vyjasněna odpovědnost za jeho uložení a údržbu: "Přes všecko připomínání zůstala věc tato posud nevyřízena, a dotyčný preparat musí se pro nedostatek př́nodného místa brzy sem brzy tam přenášeti. Uctivě podepsaný [= Vrtátko] prosí, aby záležitost tato tak nebo onak konečně byla vyřízena."

Jak byla Vrtátkova prosba bezprostředně vyřízena, není známo. Ovšem z konce 19. století je o existenci a stavu preparátu mozku Františka Palackého k disposici několik pramenů, 


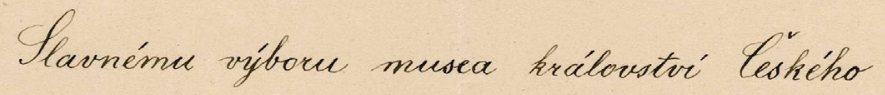

$$
\text { a. Mraze! }
$$
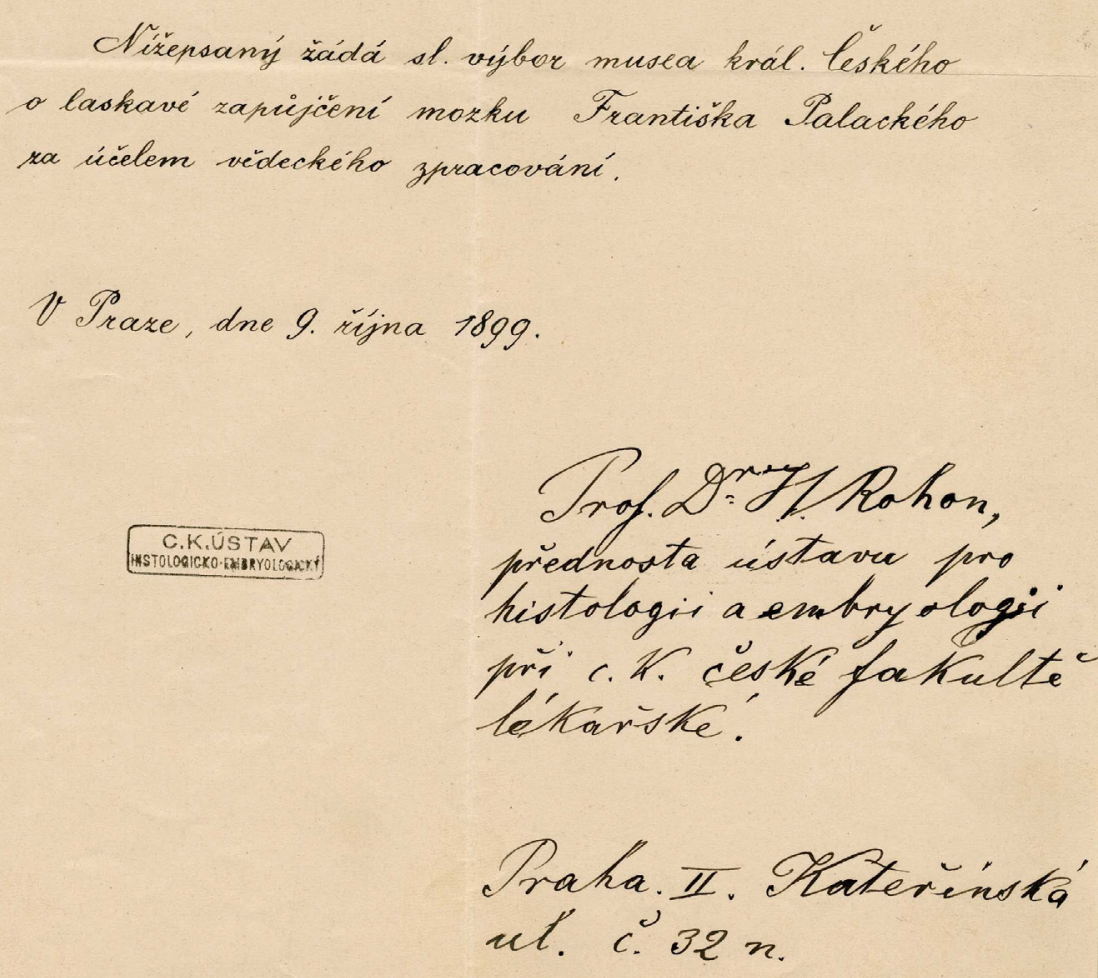

Obr. 5. Žádost profesora Josefa Viktora Rohona z roku 1899 o zapůjčení preparátu mozku Františka Palackého pro vědecké prozkoumání (RNM 1899/1086). Scan: M. Běličová. 
z nichž vyplývá, že mozek byl před rokem 1899 uchováván ve správě profesora Antonína Friče, tehdy ředitele [= čestného kurátora] zoologických a paleontologických sbírek Musea království Českého. Vzhledem k vlastní biologické podstatě preparátu a z ní vyplývajících nároků na jeho ošetření a uchování byla tedy někdy během let 1878-1899 nádoba s mozkem umístěna do zoologických sbírek [= oddělení] Musea jakožto jeho věcně nejpovolanější součásti (anthropologické sbírky dosud neexistovaly, i když jejich zřízení bylo už v té době několikrát navrhováno a požadováno). Ačkoliv zatím není přímého důkazu o tom, kdy byl Vrtátkem preparát mozku Fričovi předán, lze usuzovat, že to bylo patrně v reakci na Vrtátkův prŕípis v roce 1878 či 1879 (vzhledem k prosincovému datu př́ípisu), nejpozději však asi v období 1892-1893, po smrti A. J. Vrtátka, kdy jeho často zmiňovaná nepořádná agenda (Sklenář 2001) byla předána novému knihovníkovi, Adolfu Paterovi. Navíc se v této době (1890-1893) musejní sbírky včetně knihovny stěhovaly z dosavadní budovy Musea v ulici Na Příkopě do nově postavené budovy v čele Václavského náměstí.

Zmíněný sled dokumentů z let 1899-1900 podává obšírně svědectví o mozku Františka Palackého a manipulaci s ním. Dne 9. ř́jna 1899 podal profesor Josef Viktor Rohon, přednosta ústavu pro histologii a embryologii lékařské fakulty české Karlo-Ferdinandovy university, písemnou žádost k správnímu výboru Musea království Českého o zapůjčení mozku za účelem vědeckého zpracování (RNM 1899/1086; obr. 5). Z žádosti není zřejmé, jaké zkoumání a vědecké zpracování Rohon zamýšlel, ovšem jeho histologická specialisace a také další údaje z pramenů naznačují patrně invasivní průzkum mozkové tkáně. V reakci na Rohonovu žádost napsali hned 11. ř́jna 1899 Wácslaw Wladivoj Tomek, vicepresident Společnosti Musea království Českého, a Bohuslav Jiruš, jednatel Společnosti, dědicům Františka Palackého (RNM 1899/1119-1120), totiž jeho synovi, profesoru Janu Palackému, a jeho švakru, Františku Ladislavu Riegrovi (vdovci po Palackého dceři Marii, zeti Františka Palackého), aby se laskavě vyjádřili, zda souhlasí či nesouhlasí s lékařským výzkumem mozku Františka Palackého. Bylo totiž zřejmé, že o tom Museum samotné rozhodnout nemůže, resp. nechce. K žádosti připojili opisy dvou Rohonových př́ípisů, my však známe jen jeden, strohého obsahu (RNM 1899/1086); možná tedy Rohon stihl poslat ještě další, podrobnější, jenž se nezachoval. Ovšem může se jednat také jen o chybnou formulaci v dopise, která má zmiňovat nikoli "opis dvou přípisů", ale "dva opisy [jednoho] přípisu", nebot' dopis šel ve dvou vyhotoveních oběma dědicům zvláštt.

O aktivitách musea či dalších zúčastněných ohledně mozku Františka Palackého není z období mezi listopadem a prosincem 1899 včetně k disposici dokumentů, až 20. ledna 1900 poslal stavitel a mecenáš Josef Hlávka spolu s profesorem Bohuslavem Raymanem jménem Druhé třídy [= přírodních věd] České akademie císaře Františka Josefa pro vědy, slovesnost a umění, jíž byli představitelé (president a tajemník), vyjádření dávající odborné dobrozdání výzkumu mozku (RNM 1900/72). Aktivitu zúčastněných lze však zrekonstruovat, nebot' Hlávka s Raymanem v tomto dopise informují, že zmíněná Druhá třída na zasedání 17. listopadu 1899 předala dotaz správního výboru Společnosti Musea království Českého dvěma členům České akademie, profesorům lékařství Jaroslavu Hlavovi a Janu Janošíkovi. Ti pak "pronesli úsudek svůj v ten smysl, že k otázce, [...] odpověděti lze jen po ohledání nynějšího stavu mozku. Za tím účelem by bylo třeba láhev, v níž mozek jest uschován za prrítomnosti zvláštní komise otevříti a mohl by pak ihned, byl-li by lepší konservace schopným shledán, nově konservován býti." Ovšem ohledně výzkumu mozku se vyjádřili opatrně: "Pokud jde o vědecké zpracování, pronášejí se pp. referenti [= Hlava a Janošík] - opírajíce se o názory nejnovější - v ten smysl, že popsání gyrifikace nemá žádného významu vědeckého a že by bylo exponování mozku Palackého, který má zajisté význam po stránce piety, při nejmenším zbytečné a vyhovělo by účelu tomuto ofotografování."

Zmiňovaný dotaz správního výboru Společnosti Musea království Českého adresovaný České akademii se nedochoval, theoreticky mohl být podán i ústně - členové Společnosti Musea a České akademie byly v řadě případů totožné osoby. Dopis ovšem naznačuje také proběhlou komunikaci mezi správním výborem Společnosti a pozůstalými po Františku Palackém, kteří mohli tímto dobrozdáním podmínit svůj souhlas s vydáním preparátu moz- 


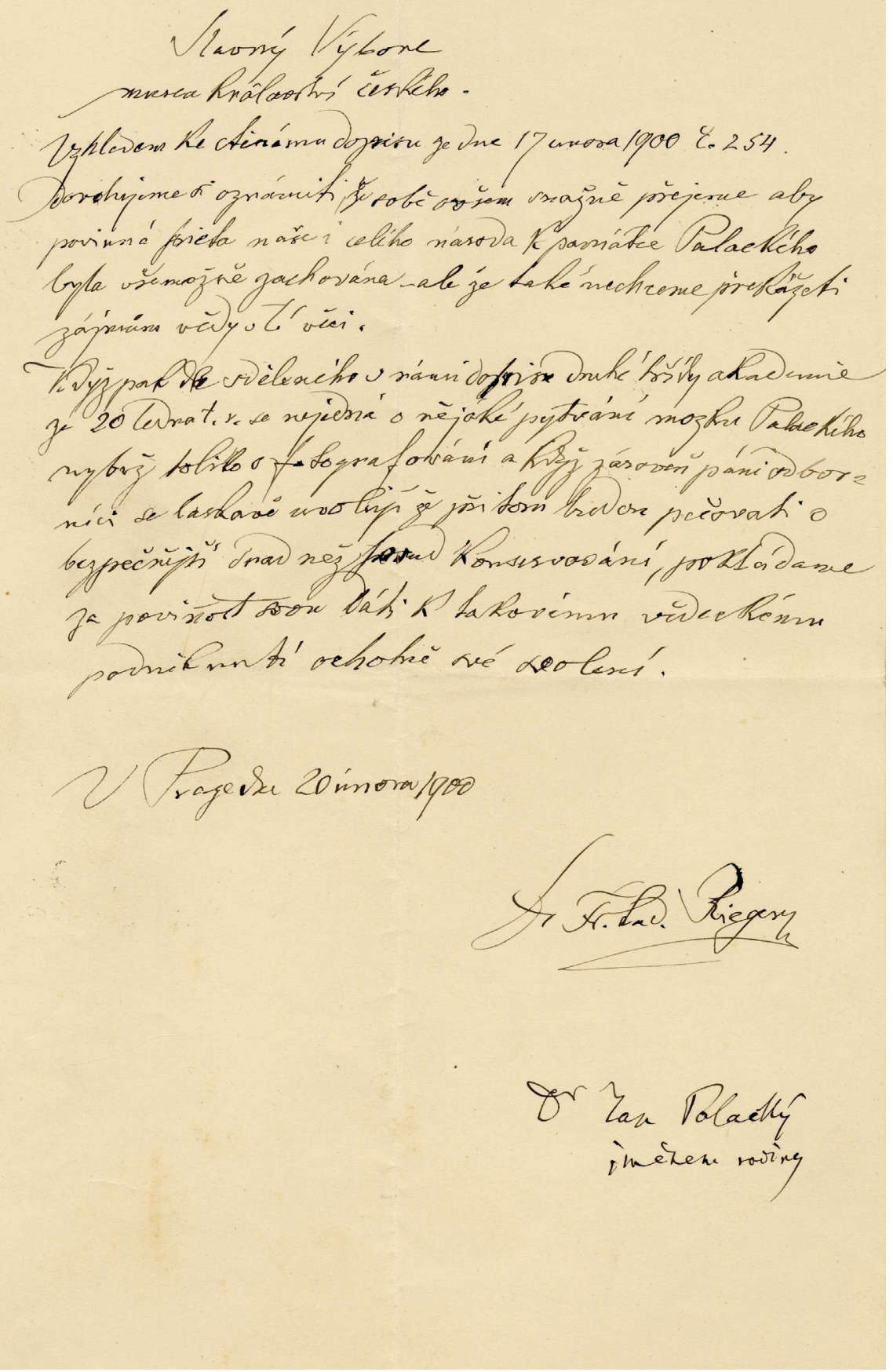

Obr. 6. Dopis Františka Ladislava Riegera a Jana Palackého z roku 1900, v němž za podmínek souhlasí s výzkumem preparátu mozku Františka Palackého (RNM 1900/259). Scan: M. Běličová. 
ku k Rohonovým výzkumům. Každopádně po necelém měsíci, 17. února 1900, napsal jednatel Společnosti Musea království Českého Jiruš poznovu dopis Riegrovi (RNM 1900/254), v němž posílá opis dobrozdání podaného Českou akademií a připojuje "prosbu, aby Vaše Vysokoblahorodí ráčilo správě musejní laskavě oznámiti, jaké stanovisko velectěná rodina zvěčnělého našeho historiografa k žádosti p. prof. Dra J. V. Rohona se zřetelem k tomuto dobrozdání zaujímá, aby správnímu výboru Společnosti musejní mohla býti o tom dle možnosti podána zpráva v nejbližší jeho schůzi, která konati se bude 24. února t. r.". Tentokrát Rieger spolu s Palackým ml. zareagovali okamžitě a Rieger 20. února 1900 napsal správnímu výboru Společnosti Musea království Českého dopis, Palackým signovaný (RNM 1900/259; obr. 6), v němž vyjadřuje, že nechtějí být překážkou ve výzkumu mozku Františka Palackého, a tedy s ním souhlasí, ovšem současně by byli rádi, kdyby byla zachována "povinná pieta naše i celého národa k památce Palackého", a tedy aby mozek nebyl pitván, pouze povrchově ohledán či fotografován.

To však ještě neznamenalo, že by byl preparát mozku předán Rohonovi. Nejprve bylo nutno komisionelně mozek prozkoumat v museu a na základě výsledku tohoto průzkumu postupovat dále, tedy jednat ve smyslu výše zmíněného návrhu v dopise Druhé tř́dy České akademie (RNM 1900/72). 0 tom se správní výbor Společnosti opravdu usnesl 24. února 1900, jak předtím naznačoval v dopise Palackého dědicům. Správní výbor Společnosti Musea království Českého nejprve musel vytvořit dotyčnou komisi, o čemž se zachovala informace v dopisu výboru Antonínu Fričovi (RNM 1900/391) z 6. března 1900. V tomto textu se poprvé jasně zmiňuje, že mozek Palackého je v péči Fričově, patrně už nějakou dobu ("chovaný dosud v oddělení Vaší Slovutnosti”). Dále je v něm Frič žádán, aby se stal členem komise, která by měla posoudit stav preparátu ("Za člena kommisse řečené dovoluje si výbor musejní povolati též Vás, Velevážený Pane, a mimo Vaši Slovutnost súčastní se jí ještě pp. univ. prof. Mudr. Jar. Hlava, univ. prof. Mudr. Jan Janošík a jednatel Společnosti musejní."), a nakonec aby sjednal podmínky, za kterých by mozek mohl být při komisionelní revisi zvážen (tzn. aby přinesl váhy).

Dotyčná komise se sešla nad preparátem mozku Františka Palackého třikrát, jak dokazují protokoly o jeho ohledání, poprvé 10 . března, pak o tři dny později a nakonec 30 . května 1900 (RNM 1900/406, 422, 819; obr. 7). Poprvé se komise sešla ve složení Antonín Frič, Jaroslav Hlava, Jan Janošík a Bohuslav Jiruš, přítomni byli dále Václav Vávra (adjunkt zoologické sbírky), František Kvapil (tajemník Musea) a Josef Rejsek (preparátor anatomického ústavu české Karlo-Ferdinandovy university); při pozdějších setkáních chyběl Hlava, resp. Hlava a Rejsek.

Text protokolu z prvního setkání komise z 10. března 1900 (RNM 1900/406) je vhodné na tomto místě citovat téměř v úplnosti, přináší úsporně popis stavu mozku a jeho řešení: "Mozek Františka Palackého odevzdán byl kommissi od p. prof. Dra Friče ve čtyřhranné skleněné nádobě sklenářským kytem přitmelené, špagátem převázané a tento připečetěn nahoře na dvou místech pečetí Museum regni Bohemiae. Pod pečetí na pravé straně byl uzel, takže tento bez porušení pečetí nemohl býti rozvázán. Zatmelení, pečeti i špagát byly shledány neporušeny. // Na to bylo přikročeno k otevření nádoby. // Při tom p. prof. Mudr. Janošík konstatoval: Mozek uložen byl v alkoholu na vatě, jest dostatečně tvrdý, na povrchu zachována arachnoidea i pia mater. // Mozek v celku jest malý, a zvážen vážil 1150 gramů. Mozek ten soudě dle povrchního doteku možno po odstranění arachnoidey a pie mater do vhodné nádoby montovati, čímž by teprv jeho uschování nabylo většího významu. [...] // Učinil se pokus se stahováním blan mozkových a tu shledáno, že toliko povrch jest následkem prvotní konservace skvělý, kdežto vnitřek jest měkký a není vyloučena možnost, že po odstranění blan a uložení do jakékoli konservační tekutiny by nastati mohlo rozpliznutí celého mozku. // Znalci navrhují konservování v glycerinu s 5\% formolem a sice z toho důvodu, že tekutina tato se nevypařuje a nemrzne, kdežto uložení do alkoholu při větších změnách teploty mohlo by při dobře uzavřené nádobě vésti $\mathrm{k}$ jejímu roztržení, při nedobře uzavřené k vyschnutí, v obojím př́ípadě ku zničení objektu. // Při provedení toho mohla by ovšem nastati eventua- 


\section{MUSEUM}

KRÁLOVSTVÍ ČESKÉHO

$\checkmark$ PRAZE.

$$
\text { Crotokotl }
$$

or Truhé schinzi Rommisse Rprohle'inuté a novénm Ronservováni montur historiografa Frentisina Galackiho,

$$
\text { jers se honala }
$$

$v$ sitery tre 13. biezner o 11. hot. Topoliotre $\checkmark$ musejum bivores.

Prítommi byli pp. ilenové Rommisse: prof. Their. Jan tanosik, iovor resta prof. Muitr. Boh. ilechtic Lisur a prof. Dr. Ant. Fric.

Dále byli pǘtommi: aijunnt p. Dr. V. Vávra, $p$. praeparator dos. Rejoest as tajemunith $F_{r}$. Krapil.

La'her byla aterrenar, Ronsistence mozsh shle-

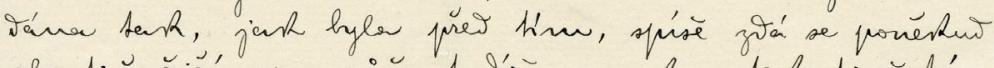


ginstati ulozen our bo bly, kby hive vlozens is be

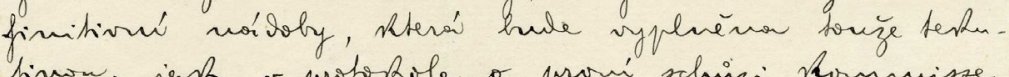

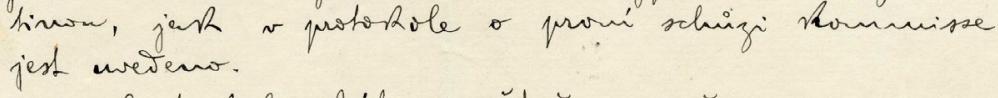
tènar

Na to byle laiber ofétué uzarrena a zapeiée.

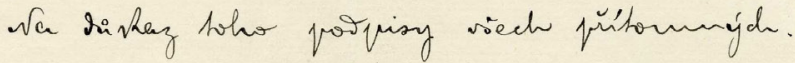

$\checkmark$ Ireare Tre 13. biezuar 1900.

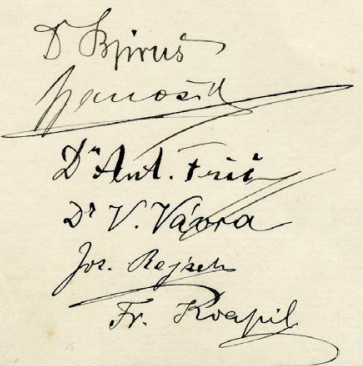

Obr. 7. Protokol z druhého komisionelního ohledání preparátu mozku Františka Palackého v březnu 1900 (RNM 1900/422). Scan: M. Běličová. 
lita, že by hmota mozková v uvedené tekutině se rozplizovala; pak by bylo nutné mozek ihned vyndati a uložiti do silného alkoholu, jako dříve byl. // Na to byl mozek uložen do hustého glycerinu s pěti procenty formolu v téže čtyřhranné nádobě skleněné, zapečetěn a ponechán opět v opatrování p. prof. Dra Ant. Friče. // Bude ovšem potřebí za dva nebo tři dny mozek opět prohlédnouti, neměkne-li snad, načež by nastala eventualita výše uvedená stran uložení jeho do silného alkoholu."

Protokol naznačuje, že mozek byl takto uložen v alkoholu nepřetržitě od vyjmutí z těla Františka Palackého, což také souhlasí se stavem mozkové tkáně. V době, kdy preparát vznikl (anebo kdy byl do zmiňované nádoby instalován či reinstalován, což se - byt' nepravděpodobně - mohlo udát i víckrát za poslední léta), patrně nebylo dostatečně (pokud vůbec) známo, že alkohol (ethanol) degraduje myelin, tedy bílkovinu (lipoprotein) představující jeden ze základních stavebních kamenů nervové tkáně a tvořící většinu bílé hmoty. Alkohol je tedy pro uchování mozku zcela nevhodný, pro fixaci nervové tkáně se dnes universálně používá formalin ("formol"), tj. roztok formaldehydu (methanalu) ve vodě. Komise tedy nechala naložit mozek do směsi glycerinu a formalinu a po třech dnech, 13. března 1900, mohla protokolárně (RNM 1900/422; obr. 7) konstatovat, že: "Láhev byla otevřena, konsistence mozku shledána tak, jak byla před tím, spíše zdá se poněkud elastičtější a může tudíž mozek v tekutině té zůstati uložen až do doby, kdy bude uložen do definitivní nádoby, která bude vyplněna touže tekutinou, jak v protokole o první schůzi kommisse jest uvedeno." Při následné komisionelní kontrole 30. května 1900 bylo už protokolárně (RNM 1900/819) zaznamenáno: "Při vyndání [z nádoby] shledán byl mozek Fr. Palackého konsistence úplně tvrdé a není žádné další obavy, že by se nějakým spůsobem mohl změniti. Po tomto zjištění vložen byl mozek do nové cylindrické nádoby průměru $18 \mathrm{~cm}$., v níž před tím nalita smíšenina $90^{\circ}$ glycerinu sehnaného [= koncentrovaného] a $10^{\circ}$ formalínu. Pak byla nádoba ovázána měchuřinou přes skleněné víko sahající a je překlopující, převázána motouzem a zapečetěna. // Láhev s mozkem Fr. Palackého odevzdána jest po té v opatrování p. adjunktu Dru V. Vávrovi." Není vyloučeno, že v témže válci spočívá preparát mozku Františka Palackého dodnes, tvarem a rozměry současná nádoba popisu odpovídá.

Po této pečlivé revisi konservace preparátu bylo konečně povoleno profesoru Rohonovi provést svůj výzkum. Správní výbor Společnosti Musea království Českého poslal 7. června 1900 Rohonovi dopis (RNM 1900/937), v němž podrobně ustanovuje podmínky, za nichž je možno mozkem manipulovat a provádět jeho výzkum: "správní výbor Musea [...] milerád Vám uděluje povolení prozkoumati mozek Palackého, jej eventuelně vyobraziti a výsledek Vašeho zkoumání uveřejniti, přičemž ovšem nutno zachovati následující podmínky: // 1) Ohledání, kreslení neb fotografování mozku smí se díti jen v budově musejní, a sice v pracovně adjunkta p. Dra. V. Vávry, který po tu dobu mozek přechovává, za něj jest zodpovědný [...]. // 2) Kdyby ohledání a studování vyžadovalo více dnů, budiž nádoba vždy po ukončení denní práce u přítomnosti p. Dra Vávry Vaší privátní pečetí zapečetěná a Dru Vávrovi odevzdána. // Po ukončení práce budiž nádoba obsahující mozek u Vaší přítomnosti od jednatele Musea museální pečetí zapečetěna, a o tom protokol sepsán. // 3) Dle výslovného přání rodiny nesmí býti mozek pitván, a tedy nesmí se ani blány mozkové kterými ještě pokryt jest, odstraniti, a rovněž nesmí býti ničeho jiného podniknuto, čím by mozek mohl býti porušen." Jak po dalších třiceti letech Vávra uvedl (RNM 1931/X/P2), za těchto podmínek profesor Rohon od úmyslu zkoumat preparát mozku Františka Palackého upustil. Rohonův původní úmysl prozkoumat Palackého mozek však vedl k tomu, že stav tohoto preparátu byl poprvé po 24 letech revidován a jeho konservace upravena tak, aby nedošlo k jeho zničení.

Poslední protokol o komisionelním ohledání preparátu mozku jakož i dopis správního výboru profesoru Rohonovi spolu udávají, že se mozek Palackého již nevrátil do péče Fričovi, řediteli zoologických sbírek, nýbrž Vávrovi, adjunktovi týchž sbírek. Tento akt však nebyl učiněn nahodile; dne 15. června 1900 obdržel Vávra od správního výboru Společnosti Musea království Českého přípis (RNM 1900/935), dle nějž je preparovaná památka na Otce národa nadále svěřena Vávrovu "bezprostřednímu dozoru" a má ji opatrovat "s největší pietou a ta- 
K čj.554 Nár. lus. ze dne 10 . prosince 1930.

Věc : Odevzdání mozku

historiografa

Fr.Palackého.

V Praze, dne 27.února 1931.

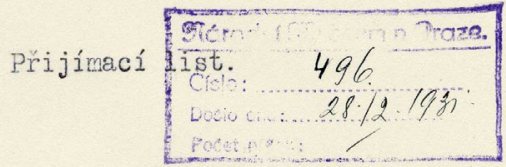

S p r áv è Národního lu us $\theta$ a

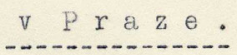

Z nařízení jednatele N.llusea pana Prof.K.

Domina $\mathrm{k}$ shora uvedenému číslu jednacímu odevzdá-

vá podepsaný skleněný válec, v němž uložen jest mozek historiografa Františka Pelackého, uzavřený pečetí Národního Irusea, panu adm.rediteli a.

Zemkovi.

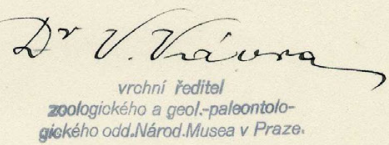

Vide:

Q27. Doming

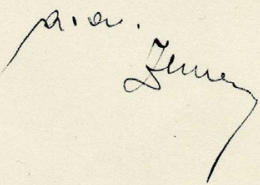

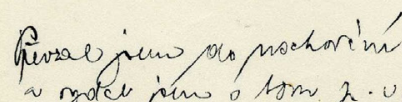

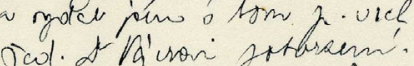

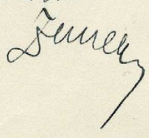

Obr. 8. Přijímací list stvrzující předání preparátu mozku Františka Palackého odcházejícím ředitelem zoologického oddělení Václavem Vávrou administrativnímu řediteli Národního musea Antonínu Zemkovi (RNM 1931/X/P1). Scan: M. Běličová. 
kovým způsobem, by žádného porušení ani poškození nedošla". Pokud by někdo chtěl mozek jen vidět, neřkuli zkoumat, je Vávra povinen vyžádat předtím schválení správním výborem anebo presidiem Společnosti Musea království Českého. Tento strohý úvodní přípis byl doplněn dopisem se shodným datem 15. června (RNM 1931/X/P4), ve kterém bylo adjunktu Vávrovi již obšírněji oznámeno, že profesor Rohon má povolení zkoumat mozek Palackého, a jenž uvedl tytéž podmínky výzkumu, které týden předtím Správní výbor zaslal Rohonovi.

Poslední archivní pramen týkající se aktivit Musea spojených s preparátem mozku Františka Palackého v letech 1899-1900 pochází ze 14. července 1900. Jedná se o dopis (RNM 1900/1190), v němž Správní výbor Musea království Českého děkuje profesoru Hlavovi za účast v komisi k prozkoumání a novému konservování mozku Františka Palackého. 0 tom, že se nejednalo jen o formální vyjádření díkủ, svědčí květnatý jazyk dopisu a také to, že jej signoval spolu s jednatelem Jirušem i president Společnosti Musea království Českého hrabě Harrach, namísto obvyklého vicepresidenta profesora Tomka.

Preparát mozku Františka Palackého pak 30 let zřejmě nerušeně spočíval ve Vávrově musejní pracovně anebo v depositáři zoologických sbírek. Rozhodně však v osobní péči Vávry, v roce 1900 adjunkta zoologických sbírek, od roku 1907 jejich kustoda - tedy ještě za aktivní služby Fričovy - a posléze, po Fričově odchodu na odpočinek, ředitele zoologických a geologických sbírek, nejprve Musea království Českého, od roku 1919 Národního musea. Když Vávra v polovině roku 1930 požádal o pensionování, strávil zřejmě následující půlrok postupným předáváním agendy zoologického oddělení svému nástupci Janu Obenbergerovi a k 1. lednu 1931 odešel na odpočinek (Obenberger ale oficielně dosedl na uvolněné Vávrovo křeslo až roku 1933). Palackého mozek však asi do zoologické agendy nepatřil, proto se Vávra ještě 10. prosince 1930 obrátil obšírným dopisem na správní výbor Společnosti Národního musea (RNM 1931/X/P2), ve kterém oznámil, že od června 1900 má osobní dozor nad mozkem Františka Palackého, popsal své zážitky z komisionelního ohledávání mozku, které obsahově odpovídají protokolům z jara roku 1900, a pak uvedl, že profesor Rohon upustil od prozkoumání mozku po sdělení podmínek umožňujících ono prozkoumání. Hlavně však uvedl, že: "Mozek zůstal tudíž nedotknutý v tom stavu, v jakém byl shora zmíněnou komisí uschován a zapečetěn." To ovšem znamená, že během 30 let vủbec nekontroloval kvalitu konservace preparátu jinak než pohledově zvnějšku nádoby, pokud vůbec. Závěrem oznámil: "Poněvadž podepsaný odchází 1. ledna 1930 [= 1931] do výslužby, odevzdává jemu svěřený mozek historiografa Fr. Palackého s vědomím a z nařízení jednatele společnosti musejní pana univ. prof. Dra K. Domina adm. řediteli Nár. Musea p. J. [= A.] Zemkovi ku prozatímnímu uschování v kanceláři musejní." To ukazuje, že obsah dopisu byl předjednán s vedením Společnosti Národního musea (resp. s jednatelem Společnosti Karlem Dominem) a že byl Vávra požádán, než mozek předá musejní kanceláři, aby předtím vypsal vše, co o preparátu ví. Dne 27. února 1931 byl podepsán Přijímací list (RNM 1931/X/P1; obr. 8), jímž je stvrzeno, že preparát mozku Františka Palackého byl předán administrativnímu řediteli Národního musea Antonínu Zemkovi. Tím bylo ukončeno přechovávání tohoto preparátu v zoologickém oddělení po prokazatelně 31 letech, pravděpodobně však po době mnohem delší, nejspíše až po 52 letech.

O dalším osudu preparátu Palackého mozku v meziválečném ani protektorátním období nebylo nalezeno žádné dokumentace, není tedy jasné, jak dlouho ono prozatímní uschování na administrativním ředitelství trvalo. Není vyloučeno, že až do Zemkova odchodu z musea v roce 1946 (kdy ovšem odcházel jako ředitel, jímž byl od roku 1940). Dalším milníkem, časově určujícím osud preparátu, je až zpráva anatomického ústavu lékařské fakulty University Karlovy, podepsaná jeho přednostou profesorem Borovanským (BAS 1949/b. č.), jež dokládá, že tento ústav měl mozek v držení na samém konci roku 1949. Zpráva dále zmiňuje, že ústav "jmenovaný preparát vrátí v měsíci lednu [1950], poněvadž je nutno ne doplniti, nýbrž zcela vyměniti konservační kapalinu". To by mohlo nasvědčovat, že preparát mozku mohl ležet nepovšimnutý v ředitelské kanceláři musea a objeven mohl být například až při přebírání kanceláře po Zemkovi novým ředitelem Gustavem Skalským a předán anatomickému ústavu 


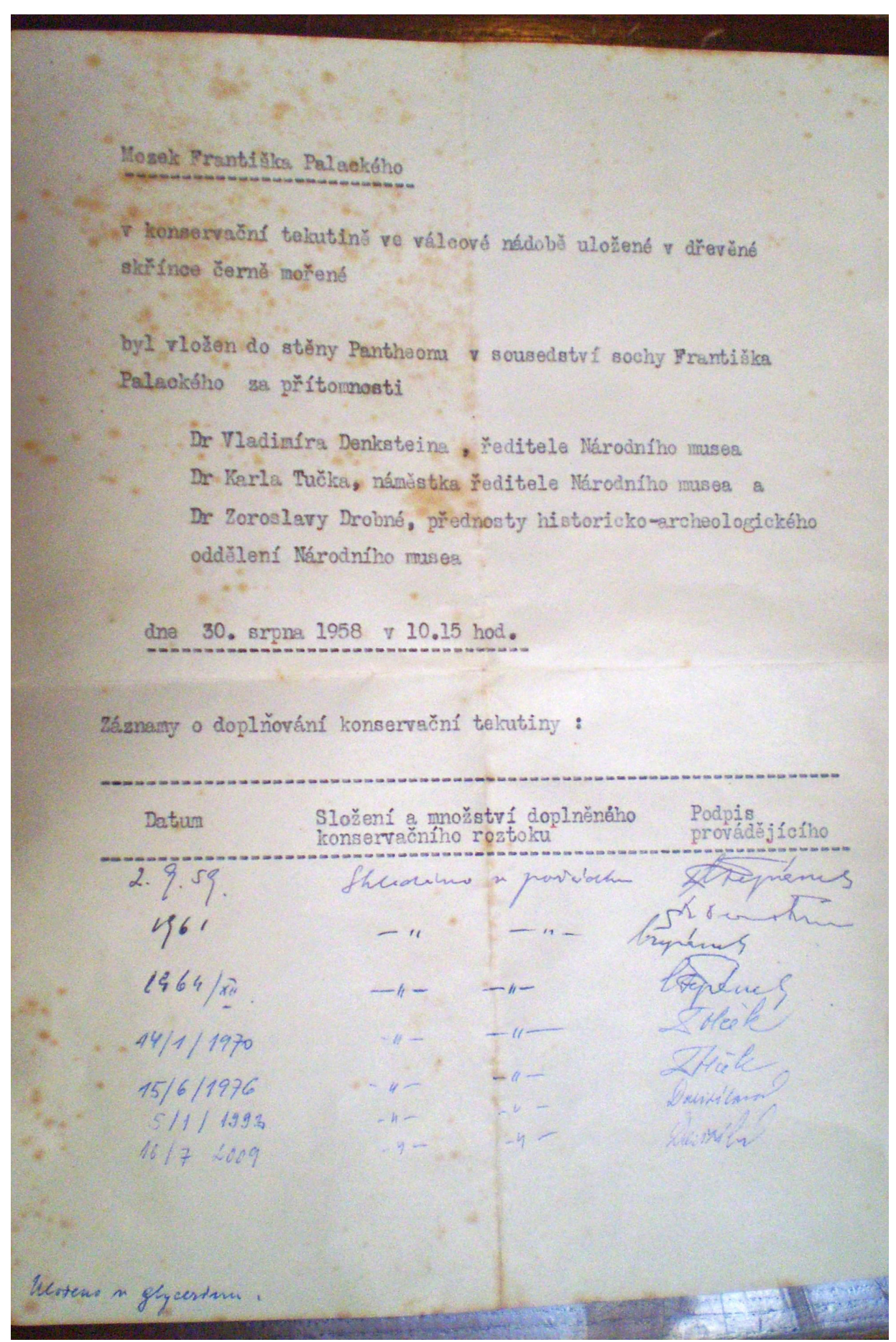

Obr. 9. Protokol o kontrolách přiložený k preparátu mozku Františka Palackého při jeho posledním trvalém uložení ve výklenku stěny sloupu Pantheonu (viz obr. 2). Foto: V. Kuželka. 
např. k revisi stavu preparátu a jeho konservace. To, že dopis zmiňuje jako věc korespondence "převzetí do úschovy", naznačuje dále, že preparát mozku mohl být v držení (úschově) anatomického ústavu delší dobu - tedy i tři roky (ale ne o mnoho více, jelikož ústav vznikl až roku 1945 nahrazením téhož ústavu zrušené Německé Karlovy university, v němž lze uložení preparátu těžko předpokládat). Každopádně preparát mozku přečkal bez úhony zásah musejní budovy bombou 7. května 1945, at' už proto, že byl deponován v nepoškozené části budovy, anebo proto, že byl spolu s jinými částmi sbírek evakuován mimo Prahu, nebo jej někdo ukryl o své újmě (takto přečkal dobu Protektorátu mozek Bedřicha Smetany upravený do podobného preparátu; Vacek 2009). Zoologické sbírky ale evakuovány nebyly, pouze přemístěny v rámci budovy do nižších pater (Švehla 1946) - pokud tedy preparát mozku spočíval opět v zoologickém oddělení, zůstal asi s ostatní sbírkou v Praze. To vše jsou však jen spekulace, osud preparátu v letech 1931-1949 prozatím zůstává neznámým.

Jen jediný údaj o mozku Františka Palackého je k disposici z období po roce 1950, jedná se o protokol připojený přímo k nádobě, ve které je preparát uložen ve výklenku stěny sloupu Pantheonu v prvním patře historické budovy Národního musea (samostatný list bez archivní signatury; obr. 9), ve své době za sochou Františka Palackého. Protokol pochází z roku 1958 (nese přesný čas uložení preparátu v Pantheonu 15. srpna v 10.15 hod.) a uvádí tento úvodní údaj: "Mozek Františka Palackého // v konservační tekutině ve válcové nádobě uložené $\mathrm{v}$ dřevěné skř́ńce černě mořené // byl vložen do stěny Pantheonu v sousedství sochy Františka Palackého za přítomnosti // Dr Vladimíra Denksteina, [...] // Dr Karla Tučka, [...] a // Dr Zoroslavy Drobné." Pak následuje tabulka pro doplňování zápisů o kontrolách preparátu, na samém dolním okraji listu je uvedena poznámka ručně zapsaná propisovací tužkou: "uloženo v glycerinu”. Z tabulky vyplývá, že stav preparátu byl zkontrolován v letech 1959, 1961, 1964, 1970, 1976, 1993 a 2009, všechny tyto nepravidelné kontroly souhlasily s tvrzením při první kontrole, totiž "shledáno v pořádku". První kontrolu provedli společně ředitel Národního musea Vladimír Denkstein a přednosta jeho zoologického oddělení Otakar Štěpánek. Další dvě kontroly provedl opět Štěpánek a po roce 1967, kdy v Národním museu vzniklo anthropologické oddělení, jeho první vedoucí Emanuel Vlček (1970 a 1976). Ten se však stal na roky 1977-1991 vedoucím referátu pro anthropologický výzkum historických osobností a vývoje člověka (vyděleného z anthropologického oddělení), a preparát mozku po tuto dobu nikdo nekontroloval, soudě dle záznamů v protokolu a zejména osobního svědectví Hany Hanákové, anthropoložky, která byla tehdy zaměstnaná ve zbytkovém anthropologickém oddělení. Po roce 1991, kdy byl Vlčkův referát opět spojen s anthropologickým oddělením a současně se jeho vedoucí stala Miluše Dobisíková, byl preparát mozku kontrolován jí. Z kontroly v roce 2009 pochází i zde presentovaná fotografie protokolu i otevřeného výklenku ve stěně sloupu (obr. 8, 2). V současné době preparát mozku Františka Palackého formálně stále zůstává v gesci anthropologického oddělení Národního musea.

Doba umístění preparátu mozku do výklenku ve zdi sloupu Pantheonu celkem dobře koresponduje s další výměnou na postu ředitele Národního musea, v září 1956 zemřel Gustav Skalský a ředitelem se stal Vladimír Denkstein. Jelikož byl preparát mozku do Pantheonu umístěn v srpnu 1958, je možné, že Denkstein mohl záhy po nástupu do funkce objevit do té doby bezprisorní a v jistém ohledu i nedůstojnou situaci preparátu mozku Františka Palackého, kterou nechal vyřešit zbudováním výklenku a uložením preparátu mozku v něm. Ovšem kde byl Denksteinem či někým dalším preparát mozku nalezen, či kde byl vlastně mozek uložen v době ředitelování Skalského od roku 1950, kdy byl s největší pravděpodobností navrácen z anatomického ústavu lékařské fakulty UK, nelze žádnými doklady doložit, podobně jako jeho předchozí osud v letech 1931-1949.

V roce 2009 byl - kromě už zmíněné kontroly množství konservační tekutiny - preparát mozku vyjmut z výklenku ve zdi sloupu Pantheonu ještě jednou, a to $\mathrm{z}$ důvodu natáčení absolventského filmu studentky Filmové a televisní fakulty Akademie musických umění v Praze Život věčný (Nováková 2009). Tento krátký film (délka 13:22 min.) by nebylo nutno 
připomínat, je přes zjevnou uměleckou ambici dosti povrchní a autorka se v něm, tak jako před ní mnoho jiných, vlastně jen veřejně vypořádává s překvapením, co vše pro ni nezvyklého může skrývat museum. Ve filmu je však veřejnosti docela otevřeně a nijak pietně předveden preparát mozku Františka Palackého - jedná se tak zřejmě o jediné publikované fotografické zaznamenání vlastního orgánu - ve filmu sice stále zůstává ve skleněném válci v dřevěné skř́ńnce, která je z výklenku sloupu vyjmuta a postavena na dlažbu Pantheonu, má však odklopenou přední stěnu tak, aby byl preparát dokonale vidět a mohl tedy náležitě diváka šokovat.

Preparát mozku Františka Palackého (téměř) nerušeně a nakonec i docela pietně spočíval skoro 57 let v Pantheonu Národního musea, tedy v situaci, která dobře odpovídá sentimentálnímu a oslavnému vztahu k Otci národa, byt’ s největší pravděpodobností v původní koncepci Pantheonu tento prvek přítomen nebyl (theoreticky by však mohl, stavba historické budovy začala devět let po smrti Palackého). Ve druhém desítiletí 21. století však došlo na dlouho připravovanou stavební rekonstrukci historické budovy Národního musea, která se dotkla i Pantheonu. V rámci vyklízení tohoto sálu došlo 15. května 2015 k přestěhování preparátu mozku z historické budovy do Památníku Františka Palackého a Františka Ladislava Riegera v Palackého ulici na Novém Městě pražském, v domě, jenž patří Palackého rodině dodnes (s určitou přestávkou). Památník představuje pietně udržovaný byt, v němž žila postupně rodina Palackého, jeho zetě Riegera a Riegerova zetě Bráfa, ve stavu odpovídajícím jeho užívání zhruba v období první československé republiky (Drobná \& Přenosilová 1999). Válcová nádoba s preparátem mozku zůstala ve stejné dřevěné černě mořené skříňce, do které byla uložena roku 1958. Tato do stran rozkládatelná skř́ńnka (obr. 1) byla dále umístěna do trojramenné uzamykatelné mřížky ze žlutého kovu upevněné ke zdi nad nočním stolkem u Palackého úmrtního lože v Palackého pracovně (obr. 3).

Mediální aktivita, jež souvisela s převozem preparátu mozku Františka Palackého a která zahrnula media seriosní a vzhledem k povaze preparátu i méně seriosní, upoutala pozornost př́mých potomků a dědiců Františka Palackého. Ti byli kromě nedůstojného rozruchu doprovázejícího stěhování preparátu zejména překvapeni diskusí o jeho možném dalším osudu, nebot' do ní nebyli vůbec zahrnuti, ačkoliv jinak byla presentována široce a byla do ní zapojena veřejnost za pomoci webové stránky musea. Už od počátku úvah o osudu preparátu během rekonstrukce historické budovy Národního musea byly uvažovány tři možnosti; kromě umístění v Památníku Palackého a Riegera, ke kterému nakonec došlo, bylo zvažováno umístit preparát mezi ostatní tekutinové preparáty do depositáře anthropologického oddělení Národního musea v Horních Počernicích, anebo jej pohřbít společně s ostatky Františka Palackého v hrobce v Lobkovicích. Zdá se, že umístění v Památníku - které jediné nakonec bylo veřejnosti presentováno - tak vlastně stojí na pomezí obou krajních řešení, která by patrně ukončila možnost vztahovat se k preparovanému mozku úžeji jako k jistého druhu relikvii či k samostatnému symbolu historických událostí a národních zápasů. Ovšem Palackého potomci, kteří později na vlastní přání vstoupili do jednání se zástupci Národního musea, nebyli jednotni v názoru na osud preparovaného mozku jejich předka (alespoň podle dojmů zúčastněných úředníků musea). Především proto se nyní počítá se zachováním preparátu in statu quo, tedy s jeho přenesením zpět do Pantheonu Národního musea a jeho ponecháním na místě do doby, než bude rozhodnuto, zda je takové umístění skutečně nejlepším řešením, anebo bude zvoleno řešení jiné.

V této souvislosti je zajímavý obsah diskuse, která se vedla na webové stránce Národního musea od května 2015, kdy byl medialisován přenos preparátu z Pantheonu historické budovy do Památníku Palackého a Riegera. Čtenáři stránky mohli v anketě hlasovat o dvou možnostech, totiž zda umístit preparát zpět do Pantheonu, anebo jej nechat pohřbít do Palackého hrobky. V tomto hlasování zvítězilo umístění v Pantheonu, pro nějž se shromáždilo 56,5 \% hlasů (173 z celkových 306). Vlastní diskuse spojené s anketou se zúčastnilo celkem šest osob, z nichž jen jedna uvedla, že pro rozhodnutí o dalším osudu preparovaného mozku by bylo vhodné znát názory potomků Františka Palackého. 
Historie preparovaného mozku Františka Palackého je tímto přehledem nejvyšší možnou měrou zrekonstruována, i když není vyloučeno, že budou nalezeny dokumenty a zaznamenané údaje, které pomohou dále osvětlit jeho dosud neznámé dějiny.

Několik skutečností zůstávají na tomto příběhu pozoruhodné; ačkoliv se jedná o svého druhu př́mý symbol historie národního zápasu, at' už jeho konkrétního anebo abstraktního vnímání, tedy památku duchovní, tak vždy byl - alespoň pokud je známo - z pochopitelných důvodů v gesci prrírodovědeckých sbírek Musea království Českého a později přírodovědeckých oddělení Národního musea (nejprve zoologických a později anthropologických). Na druhé straně, přestože byl preparát $\mathrm{v}$ držení př́rodovědných oborů, nebylo $\mathrm{s}$ ním jako s př́rodovědným preparátem zacházeno (až na vlastní konservaci). Mozek sice byl odebrán z těla Palackého mimo jiné proto, aby byl zkoumán, a to výhradně nástroji prrírodovědy (jinak by ani nebylo lze), nikdy k tomu nedošlo; jediný známý a nijak podrobný popis fysického stavu mozku Františka Palackého je k disposici ze zprávy o Palackého pitvě (Šteffal 1877). Předpokládaný podrobný rozbor látky mozkové (Šteffal) neboli chemickofysiologické proskoumání (Vrtátko), což patrně představuje destruktivní výzkum histologický, na mozku nikdy prováděn nebyl, a kromě jednoduché kontroly kvality konservace tkáně ani žádný jiný. Preparát tedy zůstává uložen v Národním museu jako památečná část těla Otce národa a budova Národního musea pro něj představuje vlastně jen odloučenou prostoru lobkovické hrobky.

\section{Závěr}

Je zvláštní a do jisté míry snad i symptomatické, že se nepodařilo dohledat bližší informace o tom, za jakých okolností bylo o vyjmutí a trvalém uchování mozku Františka Palackého rozhodnuto. Jak bylo uvedeno, $v$ dobových pramenech se hovoří příležitostně a velmi vágně o vynětí mozku pro vědecké účely, ale čí konkrétně to byl nápad a kdo nakonec učinil příslušné rozhodnutí? A co přesně bylo s mozkem zamýšleno? Měl tehdy vůbec někdo jakoukoli bližší představu o tom, kdo bude mozek vědecky zkoumat a jakými prostředky?

Úplné odpovědi na tyto otázky nemáme, nicméně představa, že průzkum mozku významného jedince umožní odhalit kořeny jeho výjimečnosti, byla v dané době mezi vzdělanci velmi živá. Jako jeden z prvních byl podroben vědeckému zkoumání mozek matematika Carla Friedricha Gausse, zesnulého roku 1855; anatom Rudolf Wagner v něm pozoroval složité mozkové závity, které byly dávány do souvislosti s Gaussovou genialitou (Gaussův mozek je součástí malé sbírky elitních mozků na Universitě Jiř́ho Augusta v Gotinkách; Schweizer a kol. 2013). Roku 1876, jen pár měsíců po úmrtí Palackého, vznikla Pařížská společnost pro vzájemnou autopsii, jejíž členové se zavázali věnovat po smrti své mozky pozůstalým členům ke zkoumání (Dias 1991). V českém prostředí byl krátce poté (1884) odebrán mozek další významné postavy národního významu, Bedřicha Smetany; jeho zkoumání bylo ale v tomto případě vedeno spíše snahou odhalit povahu závažné duševní choroby, jíž skladatel v závěru života trpěl (Vacek 2009). Určité vyvrcholení těchto snah představuje ruský Pantheon mozků založený v roce 1927 Vladimirem Mihajlovičem Bechtěrevem (dnes spadá pod moskevský Ústav lidského mozku N. P. Bechtěrevové), rozsáhlá a během 20. století průběžně doplňovaná sbírka mozků nejrůznějších př́slušníků ruské a sovětské elity (Bechtěrevův vlastní mozek je její součástí; Richter 2007).

Je ovšem třeba podtrhnout - a je to pro český kontext, domníváme se, v mnohém příznačné - že ke zkoumání Palackého mozku navzdory př́ležitostným deklaracím o plánovaném vědeckém výzkumu ve skutečnosti nikdy nedošlo. Zdá se totiž, že v jeho extrakci a zachování hrála od počátku neméně důležitou, ne-li dominantní roli memoriální a symbolická významová rovina - podobně jako tomu bylo v př́ípadě sejmutí Palackého posmrtné masky a odlitku z pravé ruky, "jež psala historii českou” (Červinková-Riegrová 1898); kopie dotyčných odlitků jsou uloženy ve sbírce anthropologického oddělení Národního musea, stejně jako v dalších sbírkách, např. v Památníku Františka Palackého v Hodslavicích (Sršeň 2010). 
Vynětí a uchování mozku ve zvláštní skleněné nádobě v českém museu "na věčnou památku", jak bylo reflektováno v dobovém tisku (Anonymus 1876e), zapojilo do služeb národoveckého hnutí některé velmi archaické prvky; s jejich pomocí pak v dobovém společenství Čechů posílilo a prohloubilo velmi osobní, afektivní prožívání jak Palackého skonu, tak výzvy udržet živý jeho buditelský odkaz.

Za připomenutí v této souvislosti stojí zejména prastará praxe oddělených pohřbů, která se aplikovala u representantů významných šlechtických rodů, nejznáměji u Habsburků, anebo v českém historickém kontextu třeba jihočeských Schwarzenberků (Grubhoffer 2013), ale také důležitých církevních činovníků. $\mathrm{V}$ souladu s touto praxí bývalo z mrtvého těla vyňato a na zvláštním místě pohřbeno srdce, přičemž ve starší tradici se ve viscerálních nádobách jinam samostatně ukládaly ještě další vnitřnosti, mezi nimi zejména játra. Ve vládnoucím rodu Habsburků se tato praxe naposledy naplno uplatnila po smrti Ferdinanda I., zvaného Dobrotivý, který byl posledním korunovaným českým králem a zemřel v Praze jen necelý rok před Františkem Palackým (29. června 1875). V souladu s habsburskými zvyklostmi proběhl jeho trojitý pohřeb ve Vídni: tělo bylo uloženo do Císařské krypty v Kapucínském klášteře, srdce do tzv. Hrobky srdcí v Loretánské kapli kostela Svatého Augustina a výběr vnitřností (plíce, játra, střeva) do Vévodské krypty dómu Svatého Štěpána (Lutovský \& Bravermannová 2007). Pradávná a silná tradice samostatného ukládání srdce tím však ani zdaleka neskončila: do Loretánské kaple bylo sice poslední srdce (arcivévody Františka Karla, bratra Ferdinanda I.) uloženo roku 1878, ale ještě arcivévoda Otto, poslední Habsburk uložený k věčnému odpočinku do Císařské krypty v roce 2011 (!), nechal své srdce pohřbít zvlášt' v mad’arském klášteře Pannonhalma, k němuž se cítil vázán silným osobním poutem.

Srdce bylo v rámci tradiční kardiocentrické perspektivy vnímáno jako centrální psycho-fysický orgán, jako samotné jádro lidské bytosti, sídlo podstaty člověka (v tradičním vidění hrála podobně významnou roli i zmíněná játra) - a zasluhovalo si tedy, obzvlášt' v případě výjimečně důležitých jedinců, po smrti speciálního zacházení. Zvláštní uložení ostatků na několika místech pak také rozšiřovalo působnost pohřebního ritu v čase i prostoru: konalo se postupně několik pohřbů a vzniklo více memoriálních míst, čímž se posilovala veřejná pamět' a v daném společenství se také pevněji ukotvovala kontinuita odkazu zemřelého. Právě poslední zmíněný faktor mohl hrát podstatnou roli i v případě Palackého: jeho tělo bylo sice uloženo v rodinné hrobce v Lobkovicích, ovšem veřejný, doslova celonárodní význam zesnulého byl jasně artikulován tím, že jeho esenciální tělesná součást (byt' již nikoli tradiční srdce, ale v souladu s vědeckou perspektivou mozek) byla zvlášt' uložena v pražském Museu království Českého. Museum jakožto instituce přitom hrálo v národoveckém hnutí zcela klíčovou roli, šlo o platformu nejen vědecko-výzkumnou a vzdělávací, ale též sociálně-politickou, již ostatně sám Palacký uváděl v život (Štaif 2009); na centrální symbolický význam města Prahy ani netřeba zvlášt' upozorňovat. Caput regni tak získala mozek, v němž se líhly Dějiny národu českého, a esence Otce národa zůstala ve své tělesné konkrétnosti příhodně i výstižně v objetí Matky měst.

Vynětí a zvláštní uložení mozku bylo jedním z prostředků, jež umožnily (velmi podobně, jako tomu bývalo $\mathrm{v}$ případě oddělených pohřbů významných šlechticů) povýšit úmrtí Palackého ze soukromé rodinné ztráty na ztrátu široce kolektivní, již utrpěl celý český národ. Týž symbolický obsah, tedy vyjádření toho, že úmrtí svým významem přesahuje ze soukromé do veřejné sféry, nesly i další složky Palackého pohřebního ritu, opět organizované zcela v souladu se starými funerálními tradicemi: kromě rozloučení nejbližších vystavení balsamovaného mrtvého těla (ostentio corpori) na několik dnů, potom celodenní pohřební průvod (kondukt) a následný pohřební obřad (zádušní mše pak byly slouženy na mnoha místech včetně zahraničí). Dobové prameny se přitom shodují v tom, že poslední dvě akce se vyznačovaly masovou účastí české veřejnosti, která se takto přišla nejen rozloučit s předním Čechem, ale též veřejně a společně přihlásit k jeho odkazu. Jak uvádí Rak (2001: 57): "Život veřejně činného národního pracovníka - 'vlastence' - byl v 19. věku z velké části pod kontrolou veřejnosti. Svou národní příslušnost byl nucen projevovat chováním, oblékáním, návštěvou určitých hostinců, kam se 
na něho ostatní národovci chodili dívat apod. [...] Skutečně veřejným majetkem se pak vlastenec stával v okamžiku své smrti - pohřeb, nápis na hrobě, pomník - to vše bylo zaměřeno k jedinému cíli: v osobě zesnulého symbolizovat ideální vlastenecké i národní ctnosti."

Význam těchto faktorů vynikne opět při srovnání úmrtí Palackého se zmíněným úmrtím excísaře Ferdinanda I. o rok dřive. Rakouská vláda se patrně obávala nepokojů, které by v českých zemích v souvislosti s touto událostí mohly nastat (jednalo se o posledního oficielního českého krále, navíc značně oblíbeného), a tak vypravila zemřelého monarchu z Prahy ve spěchu snad až nedůstojném, přičemž samotný státní pohřeb proběhl ve Vídni. České veřejnosti tehdy tudíž nebyla dopřána př́ležitost, kdy by mohla během společně zakoušeného truchlení prožít svoji rodící se kolektivní národní identitu, avšak při úmrtí Palackého následujícího roku bylo možné si tuto ušlou příležitost vynahradit. Veřejná organisace smutečních oslav (kterou na sebe vzalo město Praha) nesla rysy státního pohřbu: tělo zesnulého bylo pečlivě balsamováno a vystaveno se značnou pompou po tři dny na Staroměstské radnici; u katafalku drželi čestnou stráž sokolové a další složky společnosti; pořádek ve městě zajištovaly taktéž ozbrojené sbory pražských měštanů a hasiči v uniformách. V následujícím velkolepém pohřebním průvodu pak byly neseny desítky (až 250) praporů různých národoveckých spolků a sdružení (Anonymus 1876d).

Při zastávkách pohřebního průvodu z Prahy do Lobkovic a také při ukládání rakve do rodinné hrobky na lobkovickém hřbitově ovšem emoce gradovaly a doprovázející veřejnost postupně rozcupovala na kousky smuteční věnce - každý toužil odnést si s sebou alespoň drobnou memorii a rodině nezbylo, než nechat smuteční výzdobu zapáleným vlastencům napospas (Štaif 2009). Uvedený proces de-privatisace celonárodně významného mrtvého zachycují značně sugestivně, takř́kajíc "zevnitř", i zachované vzpomínky Palackého vnučky Marie Červinkové-Riegrové: mladá žena, která se cítila dědečkovi a jeho odkazu osobně velmi blízko, poukazuje na odcizení, které zakoušela při pohledu na balsamovanou tvář mrtvého, vystavenou pohledu davů2, a líčí, jak jí při pohřbu nezbylo než se přetahovat s třeštícími vlastenci, aby se zmocnila alespoň jedné větévky z věnce na památku po svém dědečkovi (Štaif 2001). V souhrnu toto vše poukazuje na proces až sakrální symbolisace, kterým zesnulý František Palacký procházel: památky po význačném zesnulém získávaly jakousi para-religiosní auru, stávaly se svého druhu relikviemi.

Tento pohyb, v němž v posledku nešlo o nic menšího než o překonání lidské konečnosti a dosažení nedosažitelného, tedy věčného trvání, měl přitom i svůj vysloveně tělesný rozměr. Do něho zapadá pozornost a péče věnovaná tělesné schránce a tělesným ostatkům zesnulého, včetně vyjmutí a uchování mozku. Na prvním místě ovšem samotné balsamování a aranžování mrtvého těla, které zajisté plnilo funkci esthetickou: vystavené tělo representovalo, či doslova ztělesňovalo českou národní myšlenku, a jako takové muselo vzbuzovat vážnost, respekt, vznešenost; bylo by vysoce nežádoucí, aby veřejné ostentio a jeho prožívání narušovaly nepříjemné visuální či olfaktorické vjemy (Hallam a kol. 1999). Tělo, zároveň tělo hmotné i symbolické, ideové, přetrvávalo ovšem v tomto rituálu jistým způsobem i po smrti (Král 2004), a o to zejména šlo: zajistit tímto způsobem kontinuitu a stálost Palackého odkazu zároveň na obou těchto provázaných rovinách.

Je to přitom právě tato provázanost symboličnosti a sublimované ideovosti s lidskou tělesností v její dosti hutné a drsné, smyslově konkrétní podobě, která se nám optikou zdigitalisovaného a virtualisovaného 21. století jeví jako zvláštní, obtížně pochopitelná, snad až stísňující; zvlášț pěkně to vystupuje do popředí při čtení komemorativního textu, který u příležitosti prvního výročí Palackého úmrtí publikoval v odborném lékařském periodiku Václav

2 Nepublikovaná část zápisků Marie Červinkové-Riegrové uvádí: “Dědečka nalezla jsem ale nesmírně změněného. Zdál se mi být velmi málo podoben - sobě samému - a kdybych ho byla předtím jako mrtvolu neviděla, nebyla bych ho snad poznala. Byly to ty tahy - zvláště nos karakteristický - ale nevím, co tam chybělo - nemělo to ani přivětivý úsměv, ani přísný výraz jako dřive, bylo to jako něco z vosku. Slyšela jsem později, že v tu dobu mrtvola již neměla mozek. Vyňali ho v noci pro museum - Snad proto byla tvář tak změněná. - Když bylo 10 hodin, přišli protestantští kněží, superintendent Molnár ve středu." (Vojáček in litt.). 
Šteffal, jenž tělo pitval a balsamoval (viz výše). Šteffalovi, editorům časopisu a podle všeho i jeho čtenářum přišlo zcela případné - troufáme si říci, že na rozdíl od současné společnosti, včetně lékařů - připomenout a oslavit významné národní výročí tím, že se zveřejní rok starý pitevní nález. V úvodu svůj text uvozuje zvoláním (Šteffal 1877: 169): “Kéž by tělo Palackého tak věkům vzdorovalo, jako že jim duch jeho vzdorovati bude!”, a po detailním popisu těla a vnitřností velkého muže uzavírá (p. 170): “Že jsem si na balsamování tak vzácného těla dal záležeti, seč jsem jen byl, samo se rozumí. Jak jsem se čtvrtý den po smrti při pitvání hlavy [...] přesvědčil, shodoval se k mé nevýslovné radosti výsledek se snahou mou. Jak každému známo, ležela mrtvola po několik dnů za vedra letního v zavřené ne právě veliké místnosti uprostřed velikého množství silných svící a stále skoro obklopena davem rozhřátých lidí tedy vydána vlivům pro rozklad organismu velmi příznivým; a přec neshledal nikdo z přítomných ani dosti nepatrný zápach nebo jinou stopu počínajícího hnití. Kéž by tak bylo na věky!". Máloco ukazuje lépe, jak daleko jsme se od chápání 19. století posunuli, než zvláštní (mírně řečeno) dojem, který v dnešním čtenáři budí takto pojatý vzpomínkový text. Za povšimnutí přitom zejména stojí, jak Šteffal jasně a opakovaně vyjadřuje pocitovanou souvislost mezi přetrváním tělesných ostatků Palackého a stálostí jeho ideového odkazu.

V nějaké takové perspektivě dobového podvojně tělesně-symbolického nahlížení je ovšem třeba rozumět i odebrání a uchování Palackého mozku. Při jeho extrakci bylo částečně ve hře soudobé vědecké paradigma, které podstatu lidské osobnosti umistovalo do mozku namísto tradičního srdce a věřilo, že ji zde bude možné postihnout vědeckými methodami. Nicméně dochované prameny ukazují, že pod tenkou slupkou deklarovaného zájmu o vědecké zkoumání přicházelo ke slovu mnohem spíše staré symbolické chápání, zejména pak právě pocit'ovaná velmi bezprostřední analogie mezi tělesným Palackým na straně jedné a jeho duševními schopnostmi a duchovním odkazem na straně druhé. Nedosti na tom, že zesnulý velikán měl povýtce velkou hlavu, což o něm bylo dobře známo (viz Šteffalova poznámka o kloboucích). I mozek samotný měl kvantitativně i kvalitativně, svou nadobyčejnou velikostí i očividnou krásou, přesahovat běžný průměr - po Palackého pohřbu o tom s odvoláním na Šteffala informovaly Národní Listy (Anonymus 1876e) a Světozor (Anonymus 1876b) a totéž o rok později ve větším detailu konstatoval i sám pitvukonající lékař (Šteffal 1877). Poté, co zalituje, že se pro nadbytek práce a slabý zrak nemůže pustit "do podrobného rozboru látky mozkové", připojuje pozoruhodný dovětek: "Avšak i makroskopicky shoduje se krásný ten mozek s krásným duchem Palackého, jak dalece si smíme podle stávajících vědeckých pozorování [sic!] tento závěrek dovolit." I když necháme stranou fakt, že už podle lékařů konce 19. století má Palackého mozek naprosto běžnou hmotnost i velikost (viz RNM 1900/406), je snad dosti jasné, že žádné myslitelné "vědecké" pozorování nemůže vést k závěru o korespondenci krásy mozku a krásy ducha - vlasteneckým zaujetím prodchnutý lékař se zde sice dovolává vědy, ale integrální součástí jeho "zkoumání" je vysoce zaujaté esthetické hodnocení prováděné ve službách formativního procesu národní symbolisace.

Také následná praxe nakládání s mozkem naznačuje, že nad deklarovanými vědeckými cíli převažovaly symbolické významy a ten se spíše než "preparátem" postupně stal svéráznou národní relikvií. Po zakonservování mozku a uložení nádoby do Musea království Českého se s ním dlouho nedělo vůbec nic; nezdá se, že by byla vyvíjena jakákoli aktivita směřující k tomu, aby avisované zkoumání mohlo skutečně začít. A v museu, jež bylo přece jen výzkumnou institucí, tento zvláštní předmět poněkud překážel. Více než dva roky (!) po vyjmutí a konservaci mozku čteme žádost či prosbu bibliothekáře Vrtátka, který jej měl tou dobou stále na starost a jenž si s ním ve své knihovně - nikterak překvapivě - nevěděl úplně rady, aby se konečně rozhodlo, co s ním (RNM 1878/b. č.; obr. 4). A když se celých třiadvacet let po Palackého smrti přihlásil zájemce, který chtěl mozek konečně skutečně doopravdy zkoumat (profesor Rohon), byla jeho žádost pečlivě a dlouze projednávána. Z dochované korespondence je cítit, že záležitost byla značně choulostivá, nikdo si netroufal rozhodnout ad hoc; opakovaně, až téměř varovně zaznívá, že otázka možného zkoumání mozku "dotýká se úzce otázky piety k památce našeho velikého dějepisce" (RNM 1899/1119, 1120, 1900/72, 259). 
Vyžádáno bylo i stanovisko učené komise, dotaz vznesen i na pozůstalé a konečný verdikt zněl, že provést výzkum lze, ovšem jen neinvasivní, representující jen vnější ohledání, kreslení či fotografování - tato přísná pravidla ovšem de facto jakékoli skutečné vědecké zkoumání mozkové tkáně vyloučila. A to tím spíše, že konservovaný mozek byl (a z většiny stále je) obalen měkkou plenou (omozečnicí) - komise, která v kontextu projednávání Rohonovy žádosti hodnotila stav původního preparátu, doporučovala ji z mozku odstranit, “čímž by teprv jeho uschování nabylo většího významu", rozuměj: pak teprve by z něj bylo něco vidět, snad v představě výstavní presentace. A ačkoli v témže protokolu ujištujuje, že odstraněním pleny "mozek naprosto neutrpí" (RNM 1900/406), definitivní vyjádření Správního výboru musea jasně stanovuje: "Dle výslovného přání rodiny nesmí býti mozek pitván, a tedy nesmí se ani blány mozkové, kterými jest pokryt, odstraniti, a rovněž nesmí býti ničeho jiného podniknuto, čím by mozek mohl býti porušen." (RNM 1900/937).

Svou roli v tomto striktním požadavku možná sehrálo i to, že komise složená ze špičkových odborníků se při kontrole preparátu troufale pokusila mozkovou plenu porušit, ale ukázalo se, že vnitřní tkáň nebyla dostatečně fixována a vznikla tak obava, že "by nastati mohlo rozpliznutí celého mozku" - proto se namísto toho raději přistoupilo k výměně konservační tekutiny a následným opakovaným kontrolám. Hrozivé eventualitě, že by "hmota mozková v uvedené tekutině se rozplizovala", bylo nutno za každou cenu předejít (RNM 1900/406). Podrobit mozek Otce národa jakýmkoli procedurám, které by byt' hypotheticky mohly vést $\mathrm{k}$ narušení jeho integrity, bylo tedy $\mathrm{v}$ tuto dobu vyhodnoceno jako nepřijatelné - přednost dostalo, a to jednou provždy, jeho maximálně pietní uchování v co možná původním stavu. Tedy přesně v duchu Šteffalova zvolání: "Kéž by tělo Palackého tak věkům vzdorovalo, jako že jim duch jeho vzdorovati bude!” Jako by existovala jakási hluboká vnitřní souvislost mezi kohezí národa českého a mozku jednoho z jeho otců zakladatelů ...

A tak se navzdory deklaracím o vědeckém zkoumání stalo úkolem Národního musea Palackého mozek zachovávat pro budoucnost, tedy zajišt’ovat přetrvávání tělesné esence, a tím i ideového odkazu Otce národa na věčné časy. Relikviární charakter preparátu byl definitivně stvrzen v srpnu 1958, kdy byl v dřevěné, černě lakované rozkládací truhličce uložen do výklenku sloupu Pantheonu Národního musea, v té době kousek za sochou Palackého. Patrně v této době byla také nádoba opatřena štítkem se strojopisně uvedeným jménem a roky narození a úmrtí Palackého - aby bylo provždy zcela vyloučeno zaměnit ostatky s anonymním preparátem. Národní svatostánek tehdy konečně našel adekvátní místo pro Otcův vzácný tělesný pozůstatek.

Nic ale není napořád; v souvislosti se stavební rekonstrukcí hlavní či historické budovy Národního musea se v roce 2015 znovu otevřela stará otázka "kam s ním". Tu pokládal už bibliothekář Vrtátko $v$ dávných dobách, kdy se museum ještě tísnilo $v$ budově Na Př́kopě. Církev to má snadné, ta se ke svým relikviím hlásí a má za staletí vypracované velmi přesné procedurální algoritmy, jak s nimi nakládat a jak je uchovávat. Ale museum? Příznačně a v pokračujícím duchu de-privatisace význačného národovce vyhlásila instituce $\mathrm{k}$ otázce dalšího osudu Palackého mozku veřejnou internetovou anketu - aniž by někoho napadlo položit tuto otázku též pozůstalým. Těch se to, opět, nemile dotklo; vzpomeňme v této souvislosti na Palackého vnučku a její rozporuplné pocity z pohřebních oslav. Své líčení toho, jak s Palackého tělem po smrti nakládali, pak ukončila povzdechnutím, minimálně pro část rodiny stále aktuálním: "Líto mi bylo, že s dědečkovou mrtvolou tak zacházeli, jako by jim náležela." (Červinková-Riegrová 1898). Jedna z nemnohých účastnic internetové diskuse připojené $\mathrm{k}$ anketě se přihlásila $\mathrm{k}$ myšlence, že Palackého odkaz máme udržovat živý tím, že budeme číst jeho knihy, vždyt' “jeho génius přece stále žije v jeho spisech!”. Navíc se jí nelíbí, že by měla volit, zda Palackému zapalovat svičku v Lobkovicích, nebo v Národním museu. Takovéto uvažování (směřující k tomu, že by mozek měl být pohřben spolu s tělem) poukazuje k tomu, že Palackého mozek je jakožto nositel úzce provázaných tělesně-symbolických významů zvláštním reliktem 19. věku, pro který nemusí být snadné si dnes zjednat pochopení. Vzhledem k výsledku ankety, ve které většina hlasovala pro zachování statu quo, ovšem takové v jádru ahistorické vidění přeci jen nepřevažuje. 
Nakonec byla skříňka s nádobou s preparátem mozku za značného mediálního rozruchu uložena v hlavě Palackého smrtelné postele, v původním bytě rodin Palackých a Riegerů, kde je udržována Palackého malá pracovna: skromně zařízená místnůstka s psacím stolem a úzkým tvrdým lůžkem, mimochodem značně kontrastující s velkorysostí místnosti, již měl k dispozici jeho zet' Rieger a jež svým vybavením působí poněkud procovským dojmem. Proces symbolisace, který dává již více než sto čtyřicet let Palackého mozku smysl význačné národovecké relikvie, je tedy stále při díle - a nezdá se, že by se ve své síle nějak příliš vyčerpával. Tělesná esence Otce národa se podle všeho - alespoň na čas - už brzy vrátí do sanktuaria v srdci Pantheonu národa.

\section{Poděkování}

Autoři jsou povinni díkem Lucii Čmelíkové, Jiřině Daškové, Haně Hanákové, Marku Junkovi, Kateřině Spurné, Lubomíru Sršňovi, Petru Velemínskému (Národní muzeum) a Milanu Vojáčkovi (Národní archiv ČR), kteří laskavě napomohli přípravě předloženého textu.

\section{Literatura}

Anonymus, 1876a: Nemoc a úmrtí Frant. Palackého. - Světozor 10 (22): 329.

Anonymus, 1876b: Mrtvola Palackého, vystavena na radnici staroměstské. - Světozor 10 (22): 342-343.

Anonymus, 1876c: Pohřeb. - Národní Listy 1876 (151): 1-3.

Anonymus, 1876d: Pohřeb Františka Palackého. - Světozor 10 (22): 329-330.

Anonymus, 1876e: Hlava dra. Frant. Palackého byla pytvána. - Národní Listy 1876 (152): 3.

Anonymus, 1876f: Palackýs Kopf. - Bohemia 49 (152): 5.

Červinková-Riegrová M., 1898: Poslední chvíle Františka Palackého. Ze zápisek † paní Marie Červinkové-Riegrové. - In: Nováček V. J. (ed.): Památník na oslavu stých narozenin Františka Palackého. Pp. 173-176. - Praha: Král. Česká společnost náuk, I. a III. třída České akademie císaře Františka Josefa pro vědy, slovesnost a umění, \& Matice Česká, 726 pp.

Chalupa A., Běličová M., Čechura J. \& Ryantová M., 1998: Průvodce po fondech a sbírkách Archivu Národního muzea. - Praha: Národní muzeum, 362 pp.

Dias N., 1991: La société d'autopsie mutuelle ou le dévouement absolu aux progrès de l'anthropologie. - Gradhiva 10: 26-36.

Drobná Z. \& Přenosilová V., 1999: Národní muzeum, Praha. Průvodce. Památník Františka Palackého a Františka Ladislava Riegra. - Praha: Národní muzeum, 33 pp.

Grubhoffer V., 2013: Nemoci, smrt a pohřby v životních strategiích Schwarzenbergů (17321914). - Nepubl. disertační práce. České Budějovice: Filosofická fakulta Jihočeské university, $371 \mathrm{pp}$.

Hallam E., Hockey J. \& Howarth G., 1999: Beyond the Body. Death and Social Identity. - London \& New York: Routledge, $256 \mathrm{pp}$.

Král P., 2004: Smrt a pohřby české šlechty na počátku novověku. Monografia historica 4. České Budějovice: Filosofická fakulta Jihočeské university, 320 pp.

Lutovský M. \& Bravermanová M., 2007: Hroby a hrobky našich knížat, králů a prezidentů. Praha: Libri, 223 pp.

Nováková H., 2009: Život věčný (Eternal life). - URL: https://vimeo.com/129124754.

Rak J., 2001: Pohřeb jako národní manifestace. - In: Lorenzová H. \& Petrasová T. (eds.): Fenomén smrti v české kultuře 19. století. Pp. 56-64. - Praha: Koniasch Latin Press, $425 \mathrm{pp}$.

Richter J., 2007: Pantheon of Brains: The Moscow Brain Research Institute 1925-1936. Journal of the History of the Neurosciences 16: 138-149.

Rosolová I., 2014: Vývoj správy a organisace Národního muzea v letech 1891-1914. - Časopis Národního Muzea, Řada Historická 183: 65-89. 
Schweizer R., Wittmann A. \& Frahm J., 2013: A rare anatomical variation newly identifies the brains of C. F. Gauss and C. H. Fuchs in a collection at the University of Göttingen. - Brain 137 (4): 1-2.

Sklenář K., 2001: Obraz vlasti. Př́́běh Národního muzea. - Praha: Paseka, 422 pp.

Sklenář K., 2007: Společnost Národního muzea v dějinách i v současnosti. - Praha: Společnost Národního muzea \& Nakladatelství ARSCI, 96 pp.

Šlechtová A. \& Levora J., 2004: Členové České akademie věd a umění 1890-1952. - Praha: Academia, $445 \mathrm{pp}$.

Sršeň L., 2010: Posmrtné masky a sochařské portréty. - In: Petrasová T. \& Michalíková P. (eds.): Tělo a tělesnost v české kultuře 19. století. Pp. 238-245. - Praha: Academia, 380 pp.

Štaif J., 2001: Smrt a druhý život Františka Palackého: Sondy do marginálních skutečností let 1876-1926. - In: Lorenzová H. \& Petrasová T. (eds.): Fenomén smrti v české kultuře 19. století. Pp. 267-288. - Praha: Koniasch Latin Press, 425 pp.

Štaif J., 2009: František Palacký. Život, dílo, mýtus. - Praha: Vyšehrad, 396 pp.

Šteffal V., 1877: Výsledek částečného pitvání mrtvoly Františka Palackého. - Časopis Lékařův Českých 16 (22): 169-170.

Štěpánek O., 1975: Stopadesát let zoologie Národního muzea v Praze (1818-1968). - Časopis Národního Muzea, Oddíl Př́rodovědný 138-139: 1-159.

Švehla J., 1946: Bomby kolem Pantheonu. - Praha: Nakladatelství Pragotisk, 107 pp.

Tomeš J. \& Léblová A. (eds.), 1992: Československý biografický slovník. - Praha: Encyklopedický institut ČSAV \& Academia, 837 pp.

Třeštík D., 1997: Počátky Přemyslovců. Vstup Čechů do Dějin (530-935). - Praha: Nakladatelství Lidové Noviny, 658 pp.

Vacek J., 2009: Choroba Bedřicha Smetany - spekulace bez konce? (2. část). - Česká a Slovenská Psychiatrie 105 (4): 181-188.

Woitschová K. \& Jůn L., 2019: Národní muzeum v éře Československa. - Praha: Národní muzeum, $368 \mathrm{pp}$.

\section{APPENDIX 1}

Soupis archivních pramenů v chronologickém pořadí s úplným přepisem obsahu (RNM = Registratura Národního musea)

RNM, karton 29, 1878/b. č. [= bez čísla] [dopis, rukopis, 2 pp] (obr. 4).

V př́čině anatomického preparatu // od pohřbu p. Dra Frt. Palackého

Hned po pohřbu zemského historiografa pana Dra Františka Palackého byl mozek slavného učence tohoto v lihu Museu odevzdán, aby pak panu Med Dru Václ. Štefalovi vydán byl kvůli chemickofysiologickému proskoumání. Přes všecko připomínání zůstala věc tato posud nevyřizena, a dotyčný preparat musí se pro nedostatek př́hodného místa brzy sem brzy tam prenášeti. Uctivě podepsaný prosí, aby záležitost tato tak nebo onak konečně byla vyřízena.

V Praze dne 10 pros. 1878

[podpis:] A. J. Vrtátko 
RNM, karton 52, 1899/1086 [dopis, rukopis, 1 p] (obr. 5)

Slavnému výboru musea království Českého v Praze!

Nížepsaný žádá sl. výbor musea král. Českého o laskavé zapůjčení mozku Františka Palackého za účelem vědeckého zpracování.

V Praze, dne 9. ř́jna 1899.

[podpis:] Prof. Dr. J. V. Rohon,

přednosta ústavu pro histologii a embryologii při c. $k$. české fakultě lékařské.

Praha. II. Kateřinská // ul. č. 32 n.

[razítko:] C.K. ÚSTAV // HISTOLOGICKO-EMBRYOLOGICKÝ

RNM, karton 52, 1899/1119-1120 [koncept dopisu, rukopis, 1 p]

Vaše Vysokoblahorodí! // Slovutný Pane!

Přednosta ústavu pro histologii a embryologii při c. k. fakultě lékařské české university prof. Mudr. J. V. Rohon požádal správní výbor Musea království Českého, aby mu byl zapůjčen chovaný v Museu mozek slovutného historiografa Františka Palackého za účelem vědeckého zpracování. // Ježto žádost ta dotýká se úzce otázky piety k památce našeho velikého dějepisce, dovoluje si v plné úctě podepsané praesidium dř́ve ještě, nežli věc předložena bude výboru musejnímu, požádati Vaše Vysokoblahorodí za laskavé vyjádření o svrchu uvedené žádosti. // Nebot' výbor musejní nemůže se v jednání o ní vủbec pouštěti, pokud by k tomu od velectěné rodiny historiografa Františka Palackého nebylo dáno svolení. // Opis dvou př́pisů p. prof. Mudra J. V. Rohona dovoluje si uctivě podepsané praesidium sub A) a sub B) současně přiložiti.

V Praze dne 11. ř́jna 1899. // Z praesidia Společnosti Musea král. Českého:

Vice-Praesident: // [podpis:] W. W. Tomek

Jednatel: // [podpis:] Dr B Jiruš

Č. 1120 // 1. Jeho Vysokoblahorodí Slovutnému Pánu Panu Judru Fr. Lad. baronu Riegrovi, rytírí ř́du železné koruny, členu rak. panské sněmovny, majiteli velkostatku atd. atd. v Praze.

Č. 1119. // 2. J. V. S. P. P. Dru Janu Palackému, professoru české university Karlo-Ferdinandovy, členu Král. České Společnosti Nauk a jiných společností, atd. atd. v Praze.

RNM, karton 53, 1900/72 [dopis na hlavičkovém dopisním papíru, rukopis, 2 pp] ČESKÁ AKADEMIE // CÍSAŘE FRANTIŠKA JOSEFA // PRO VĚDY, SLOVESNOST A UMĚNÍ

Slavný výbore // Musea království Českého!

Druhá třída České Akademie přikázala dotaz sl. výboru Musea král. Českého v příčině konservování a vědeckého zpracování mozku slavného historiografa Františka Palackého v zasedání svém dne 17. listopadu m. r. konaném pp. Dru. Jar. Hlavovi a J. Janošíkovi k podání dobrého zdání. // Jmenovaní odborníci pronesli úsudek svi̊j v ten smysl, že k otázce, zda jest mozek Frant. Palackého schopen lepší konservace, a zdali by při tom snad pohromu neutrpěl, odpověděti lze jen po ohledání nynějšího stavu mozku. Za tím účelem by bylo třeba láhev, v níž mozek jest uschován za přítomnosti zvláštní komise otevříti a mohl by pak ihned, byl-li by lepší konservace schopným shledán, nově konservován býti. I uvolují se jmenovaní páni prof. Hlava a Janošík spolu s praeparatorem české fakulty lékařské práci tuto provésti. // Pokud jde o vědecké zpracování, pronášejí se pp. referenti - opírajíce se o názory nejnovější - v ten smysl, že popsání gyrifikace nemá žádného významu vědeckého a že by bylo exponování mozku Palackého, který má zajisté význam po stránce piety, při nejmenším zbytečné a vyhovělo by účelu tomuto ofo- 
tografování, které by za př́ležitosti konservace provedeno býti mohlo. // Druhá třída České Akademie jednomyslně připojila se k názoru pp. referentů.

V Praze dne 20. ledna 1900.

[podpis:] Josef Hlávka // t. č. praesident

[podpis:] Dr Bohuslav Rayman // t. č. gen. sekretár

RNM, karton 53, 1900/254 [koncept dopisu, rukopis, 1 p]

Vaše Vysokoblahorodí! // Slovutný Pane!

V plné úctě podepsaný jednatel dovoluje si zaslati Vašemu Vysokoblahorodí přiložený opis dobrozdání druhé třídy České akademie ve př́čině konservování a vědeckého zpracování mozku slovutného historiografa Františka Palackého k laskavému nahlédnutí. // Zároveň dovoluje se uctivě podepsaný připojiti prosbu, aby Vaše Vysokoblahorodí ráčilo správě musejní laskavě oznámiti, jaké stanovisko velectěná rodina zvěčnělého našeho historiografa $k$ žádosti p. prof. Dra J. V. Rohona se zřetelem $k$ tomuto dobrozdání zaujímá, aby správnímu výboru Společnosti musejní mohla býti o tom dle možnosti podána zpráva v nejbližší jeho schủzi, která konati se bude 24. února t. $r$.

V Praze dne 17. února 1900.

Jednatel Společnosti Musea král. Českého // [podpis:] Dr B Jiruš

Jeho Vysokoblahorodí // Slovutnému Pánu Panu Judru Fr. Lad. baronu Riegrovi, rytíři řádu železné koruny, členu rak. panské sněmovny, majiteli velkostatku atd. atd. v Praze.

RNM, karton 53, 1900/259 [dopis, rukopis, 2 pp] (obr. 6)

Slavnému výboru musea království českého

Dr Fr Lad Rieger a prof Jan Palacký

vyslovují se o ohledání mozku Palackého

Slavný Výbore // musea království českého.

Vzhledem ke ctěnému dopisu ze dne 17 února 1900 č. 254. // Dovolujeme si oznámiti, že sobě ovšem snažně prejeme aby povinná pieta naše i celého národa k památce Palackého byla všemožně zachována - ale také nechceme překážeti zájmům vědy v té věci. // Když dle sděleného $v$ námi dopise druhé tř́dy akademie ze dne 20 ledna t. r. se nejedná o nějaké pytvání mozku Palackého nýbrž toliko o fotografování a když zároveň páni odborníci se laskavě uvolují že při tom budou pečovati o bezpečnější snad než posud konservování, pokládáme za povinnost svou dáti k takovému vědeckému podniknutí ochotně své svolení.

V Praze dne 20 února 1900

[podpis:] Dr Fr. Lad. Rieger

[podpis:] Dr Jan Palacký // jménem rodiny

RNM, karton 53, 1900/391 [koncept dopisu, rukopis, 2 pp]

Vaše Slovutnosti! // Velevážený Pane!

Se zřetelem $k$ vyžádanému dobrozdání slavné druhé třídy České akademie pro vědy, slovesnost a umění usnesl se v úctě podepsaný správní výbor, aby mozek slovutného našeho historiografa Františka Palackého, chovaný dosud v oddělení Vaší Slovutnosti, byl prohlédnut od zvláštní kommisse, která by jej dle možnosti a potreby s pomocí praeparatora české fakulty lékařské též nově 
konservovala a výboru musejnímu určité návrhy podala, zdali a jakým způsobem mohlo by se vyhověti prání p. univ. prof. Mudra J. V. Rohona, jenž požádal za dovolení k vědeckému spracování a publikování vzácné té památky. // Za člena kommisse řečené dovoluje si výbor musejní povolati též Vás, Velevážený Pane, a mimo Vaši Slovutnost súčastní se jí ještě pp. univ. prof. Mudr. Jar. Hlava, univ. prof. Mudr. Jan Janošík a jednatel Společnosti musejní. // Prohlédnutí mozku a po prípadě jeho nové konservování dít se bude v místnosti praeparatora musejní sbírky zoologické. // Den a hodina schůze kommisse budou ustanoveny později a Vaší Slovutnosti včas oznámeny. // Čině o tom Vaší Slovutnosti zdvořilé sdělení žádá spolu v úctě podepsaný správní výbor, abyste, Velevážený Pane, se neobtěžoval učiniti zároveň opatření, by mozek slovutného našeho historiografa mohl býti při jeho prohlédnutí též zvážen.

V Praze dne 6. března 1900.

Za správní výbor Společnosti Musea král. Českého

Vicepraesident: // [podpis:] WW Tomek

Jednatel: // [podpis:] Dr B Jiruš

Jeho Slovutnosti // Veleváženému Pánu Panu Dru Ant. Fričovi, professoru české university Karlo-Ferdinandovy, řediteli zoologických a geologicko-paleontologických sbírek Musea král. Českého atd. atd. // v Praze

RNM, karton 53, 1900/406 [protokol, rukopis na hlavičkovém dopisním papíru, 3 pp] MUSEUM // KRÁLOVSTVÍ ČESKÉHO // V PRAZE.

\section{Protokoll}

o schůzi kommisse $k$ prohlédnutí a novému konservování mozku historiografa Františka Palackého, která ve smyslu usnesení správního výboru Společnosti Musea království Českého ze dne 24. února 1900. se konala v sobotu dne 10. března o 11. hod. dopolední v musejní budově. // Př́tomni byli pp. členové kommisse: prof. Mudr. Jan Janošík, prof. Mudr. Jar. Hlava, dvor. rada prof. Mudr. Boh. šlechtic Jiruš a prof. MDr. Ant. Frič // Dále byli př́tomni: adjunkt sbírky zoologické Dr. Václav Vávra, tajemník Fr. Kvapil a praeparator Jos. Rejsek.

Mozek Františka Palackého odevzdán byl kommissi od p. prof. Dra Friče ve čtyřhranné skleněné nádobě sklenářským kytem přitmelené, špagátem převázané a tento připečetěn nahoře na dvou místech pečetí Museum regni Bohemiae. Pod pečetí na pravé straně byl uzel, takže tento bez porušení pečetí nemohl býti rozvázán. Zatmelení, pečeti i špagát byly shledány neporušeny. // Na to bylo přikročeno k otevření nádoby. // Při tom p. prof. Mudr. Janošík konstatoval: Mozek uložen byl v alkoholu na vatě, jest dostatečně tvrdý, na povrchu zachována arachnoidea i pia mater. // Mozek v celku jest malý, a zvážen vážil 1150 gramů. Mozek ten soudě dle povrchního doteku možno po odstranění arachnoidey a pie mater do vhodné nádoby montovati, čímž by teprv jeho uschování nabylo většího významu. Tím mozek naprosto neutrpí a po montování ve vhodné nádobě bylo by možno předsevzíti jeho fotografování a eventualní disposice dáti. // Učinil se pokus se stahováním blan mozkových a tu shledáno, že toliko povrch jest následkem prvotní konservace skvělý, kdežto vnitřek jest měkký a není vyloučena možnost, že po odstranění blan a uložení do jakékoli konservační tekutiny by nastati mohlo rozpliznutí celého mozku. // Znalci navrhují konservování $v$ glycerinu s 5\% formolem a sice z toho důvodu, že tekutina tato se nevypařuje a nemrzne, kdežto uložení do alkoholu při větších změnách teploty mohlo by při dobře uzavřené nádobě vésti k jejímu roztržení, při nedobře uzavřené $k$ vyschnutí, v obojím př́padě ku zničení objektu. // Při provedení toho mohla by ovšem nastati eventualita, že by hmota mozková $v$ uvedené tekutině se rozplizovala; pak by bylo nutné mozek ihned vyndati a uložiti do silného alkoholu, jako dř́ve byl. // Na to byl mozek uložen do hustého glycerinu s pěti procenty formolu v téže čtyřhranné nádobě skleněné, zapečetěn a ponechán opět v opatrování p. prof. Dra Ant. Friče. // Bude ovšem potřebí za dva nebo tři dny mozek opět prohlédnouti, 
neměkne-li snad, načež by nastala eventualita výše uvedená stran uložení jeho do silného alkoholu. // Na důkaz toho podpisy všech př́tomných.

V Praze dne 10. brezna 1900.

[podpisy:]

Dr B Jiruš // Prof Dr Hlava // JJanošík // Dr Ant. Frič // Jos. Rejsek // Dr V. Vávra // Fr. Kvapil

RNM, karton 53, 1900/422 [protokol, rukopis na hlavičkovém dopisním papíru, 1 p] (obr. 7)

MUSEUM // KRÁLOVSTVÍ ČESKÉHO // V PRAZE.

Protokoll

o druhé schůzi kommisse k prohlédnutí a novému konservování mozku historiografa Františka Palackého, jež se konala v úterý dne 13. brezna o 11. hod. dopoledne v musejní budově. // Př́tomni byli pp. členové kommisse: prof. Mudr. Jan Janošík, dvor. rada prof. Mudr. Boh. šlechtic Jiruš a prof. Dr. Ant. Frič. // Dále byli př́tomni: adjunkt p. Dr. V. Vávra, p. praeparator Jos. Rejsek a tajemník Fr. Kvapil.

Láhev byla otevřena, konsistence mozku shledána tak, jak byla před tím, spíše zdá se poněkud elastičtější a může tudíž mozek v tekutině té zůstati uložen až do doby, kdy bude uložen do definitivní nádoby, která bude vyplněna touže tekutinou, jak v protokole o první schůzi kommisse jest uvedeno. // Na to byla láhev opětně uzavřena a zapečetěna. // Na důkaz toho podpisy všech prítomných.

V Praze dne 13. března 1900.

[podpisy:] Dr B Jiruš // JJanošík // Dr Ant. Frič // Dr V. Vávra // Jos. Rejsek // Fr. Kvapil

RNM, karton 53, 1900/819 [protokol, rukopis na hlavičkovém dopisním papíru, 1 p]

MUSEUM // KRÁLOVSTVÍ ČESKÉHO // V PRAZE.

Protokol

o třetí schůzi kommisse k prohlédnutí a novému konservování mozku historiografa Františka Palackého, jež se konala ve středu dne 30. května 1900. o 11. hod. dopoledne v musejní budově. // Př́tomni byli pp. členové kommisse: prof. Mudr. Jan Janošík, dvor. rada prof. Mudr. Boh. šlechtic Jiruš a prof. Dr. Ant. Frič. // Dále byli př́tomni: adjunkt p. Dr. V. Vávra a tajemník Fr. Kvapil.

Láhev byla shledána náležitě uzavřena a pečeti na ní neporušeny. Na to jest láhev otevřena. Při vyndání shledán byl mozek Fr. Palackého konsistence úplně tvrdé a není žádné další obavy, že by se nějakým spůsobem mohl změniti. Po tomto zjištění vložen byl mozek do nové cylindrické nádoby průměru $18 \mathrm{~cm}$., v níž pred tím nalita smíšenina $90^{\circ}$ glycerinu sehnaného a $10^{\circ}$ formalínu. Pak byla nádoba ovázána měchuřinou pres skleněné víko sahající a je překlopující, převázána motouzem a zapečetěna. // Láhev s mozkem Fr. Palackého odevzdána jest po té v opatrování p. adjunktu Dru V. Vávrovi. // Na důkaz toho podpisy všech př́tomných.

V Praze dne 30. května 1900.

[podpisy:] Dr V. Vávra // Fr. Kvapil // Dr B Jiruš // JJanošík // Dr Ant Frič

RNM, karton 53, 1900/937 [koncept dopisu, rukopis, 2 pp]

Slovutný pane professore!

V plné úctě podepsaný správní výbor Musea království Českého klade si za čest sděliti Vám, že dorozuměv se s rodinou zesnulého historiografa Fr. Palackého, milerád Vám uděluje povolení prozkoumati mozek Palackého, jej eventuelně vyobraziti a výsledek Vašeho zkoumání uveřej- 
niti, přičemž ovšem nutno zachovati následující podmínky: // 1) Ohledání, kreslení neb fotografování mozku smí se díti jen v budově musejní, a sice v pracovně adjunkta $p$. Dra. V. Vávry, který po tu dobu mozek přechovává, za něj jest zodpovědný, a kterému bude nařízeno, aby Vám mozek $k$ účelu uvedenému propůjčil. // 2) Kdyby ohledání a studování vyžadovalo více dnü, budiž nádoba vždy po ukončení denní práce u př́tomnosti p. Dra Vávry Vaší privátní pečetí zapečetěná a Dru Vávrovi odevzdána. // Po ukončení práce budiž nádoba obsahující mozek u Vaší př́tomnosti od jednatele Musea museální pečetí zapečetěna, a o tom protokol sepsán. //3) Dle výslovného přání rodiny nesmí býti mozek pitván, a tedy nesmí se ani blány mozkové kterými ještě pokryt jest, odstraniti, a rovněž nesmí býti ničeho jiného podniknuto, čím by mozek mohl býti porušen.

V Praze dne 7. června 1900.

Za správní výbor Společnosti Musea království Českého:

Vicepraesident: // [podpis:] W. W. Tomek

Jednatel: // [podpis:] Dr B Jiruš

Jeho Slovutnosti // Veleváženému Pánu Panu // MuDru Josefu Viktoru Rohonovi, // professoru české university Karlo-Ferdinandovy, přednostovi c. $k$. ústavu histologicko-embryologického atd. atd. // v Praze.

RNM, karton 53, 1900/935 [koncept dopisu, rukopis, 1 p]

\section{Vaše Blahorodí!}

Podepsaný správní výbor usnesl se ve své poslední schůzi dne 7. června t.r. konané, aby mozek historiografa Františka Palackého, chovaný v Museu král. Českého v opatrování p. ředitele prof. Dra Antonína Friče, svěřen byl nadále bezprostřednímu dozoru Vašeho Blahorodí, a to na tak dlouho, pokud od výboru musejního nebude v té přícině jinak ustanoveno. // Dávaje o tom Vašemu Blahorodí věděti, podepsaný správní výbor spolu očekává a žádá, abyste vzácnou tu památku na nezapomenutelného historiografa našeho opatroval s největší pietou a takovým způsobem, by žádného porušení ani poškození nedošla. // Př́padné prohlédnutí, zkoumání, fotografování apod. mozku Palackého díti se mủže jedině po prededchozím schválení výboru nebo praesidia Společnosti Musea království Českého.

V Praze, dne 15. června 1900.

Za správní výbor Společnosti // Musea král. Českého:

Vicepraesident: // [podpis:] W. W. Tomek

Jednatel: // [podpis:] Dr B Jiruš

Jeho Blahorodí Pánu Panu // Dru Václavu Vávrovi, // adjunktu zoologických sbírek // Musea král. Českého //v Praze.

RNM, karton 114, 1931/X/P4 [dopis, strojopis (opis originálu), 1 p]

Opis

Museum // Království Českého // v Praze.

Jeho Blahorodí // Pánu Panu // Dru Václavu Vávrovi, // adjunktu zoologických sbírek // Musea král. Českého v Praze.

Číslo: 936

Vaše Blahorodí!

Podepsaný správní výbor usnesl se ve své poslední schůzi dne 7. června t.r. konané, aby p. MUDru Josefu Viktoru Rohonovi, profesoru české university Karlo-Ferdinandovy, dovoleno 
bylo vzhledem k dřívější jeho žádosti prozkoumati mozek historiografa Františka Palackého, chovaný v Museu král. Českého a Vašemu opatrování i stálému dozoru svěřený, a to za následujících podmínek: // 1/ Ohledání, kreslení neb fotografování mozku smí se díti jen v budově musejní, a sice v pracovně Vaší a za Vašeho nepřetržitého dohledu, Vy pak, propůjčuje památku tu k účelu svrchu uvedenému p. prof. MUDru Rohonovi, jste zodpověden za její úplné neporušení a nepoškození. // 2/ Kdyby ohledání a studování vyžadovalo více dnů, budiž nádoba vždy po ukončení denní práce u přítomnosti Vašeho Blahorodí privátní pečetí p. prof. MUDra Rohona zapečetěna a Vám opět odevzdána. // Po ukončení práce bude nádoba mozek obsahující za př́tomnosti Vaší a p. prof. MUDra Rohona od jednatele Musea pečetí musejní zapečetěna a o tom protokol bude sepsán. // 3/ Dle výslovného přání rodiny Palackého nesmí býti mozek pitván, a tedy se nesmí ani blány mozkové, kterými ještě pokryt jest, odstraniti, a rovněž nesmí býti ničeho jiného podniknuto, čím by mozek mohl býti porušen. // Dávaje o tomto svém usnesení Vašemu Blahorodí věděti, podepsaný správní výbor zároveň Vás zmocňuje, mozek Františka Palackého za podmínek svrchu řečených p. prof. MUDru Rohonovi k naznačenému účelu propůjčiti. // Den, kdy zkoumání památky té bude od p. prof. MUDra Rohona předsevzato, budiž oznámen současně správě Musea král. Českého.

V Praze, dne 15. června 1900.

Za správní výbor Společnosti // Musea král. Českého

Jednatel: // Dr. B. Jiruš. v.r.

Vicepresident: // W. W. Tomek. v.r.

RNM, karton 54, 1900/1190 [koncept dopisu, rukopis, 2 pp]

Vaše Slovutnosti! // Vysoce Vážený Pane!

$V$ plné úctě podepsaný správní výbor přijal se zvláštním potěšením na vědomí, že Vaše Slovutnosti, uvolivši se z vlastenecké obětavosti míti účastenství v kommissi, kteréž od výboru musejního bylo svěreno prozkoumati a nově konservovati mozek slovutného našeho historiografa Františka Palackého v Museu král. Českého chovaný, přispěla svým znaleckým dobrozdáním co nejplatněji k tomu, že práce s tím spojené s úplným zdarem se potkaly, tak že převzácná ona památka ve stavu zcela neporušeném pro všechnu budoucnost zachována býti může. // Koná tudíž v plné úctě podepsaný správní výbor jen milou svoji povinnost, když si dovoluje za tuto vzácnou ochotu a projevenou tím nevšední prízeň $k$ vlasteneckému ústavu našemu vysloviti Vaší Slovutnosti své nejvřelejší díky. // Zároveň dovoluje si musejní výbor připojiti uctivou prosbu, abyste, Vysoce Vážený Pane, ráčil i na prríště Museum království Českého v tutéž laskavou blahovůli a př́zeň dobrotivě zachovati.

V Praze dne 14. července 1900.

Za správní výbor Společnosti Musea království Českého:

Praesident: // [podpis:] Harrach

Jednatel: // [podpis:] Dr B Jiruš

Jeho Slovutnosti // Vysoce Váženému Pánu Panu Mudru Jaroslavu Hlavovi, professoru české university Karlo-Ferdinandovy, řediteli c. $k$. ústavu pathologicko-anatomického, čestnému doktoru Jagellonské university $v$ Krakově, atd. atd. v Praze

RNM, karton 114, 1931/X/P2 [dopis, signovaný strojopis, 2 pp]

Zoologické oddělení Národního Musea // v Praze II-1700

V Praze, dne 10. prosince 1930.

Čj. 554.

Věc: Odevzdání mozku // historiografa // Fr. Palackého. 
Správnímu výboru Národního Musea // v Praze.

Podepsanému svěřen byl dekretem ze dne 15. června 1900 čís. 935. usnesením správního výboru ve schůzi dne 7. června 1900 mozek historiografa Fr. Palackého k bezprostřednímu dozoru a uschování před porušením a poškozením. // Zároveň v téže schůzi výboru bylo usneseno, aby dovoleno bylo p. MUDru Jos. V. Rohonovi, profesoru české university KarloFerdinandovy, prozkoumati mozek F. Palackého, mému opatrování svěřený, za jistých podmínek. // Zároveň však usneseno, aby zvláštní komise, sestávající z pánů: jednatele společnosti musejní Prof. MUDra B. Jiruše, univ. prof. MUDra Jaroslava Hlavy, univ. prof. MUDra Jana Janošíka a podepsaného, tehdy adjunkta zoologických sbírek Dra V. Vávry, přesvědčila se o stavu konservace tohoto mozku a podala dobrozdání, zda má se povoliti prozkoumání jeho univ. prof. MUDru J. Rohonovi. // Jednatel musejní Prof. Dr. Jiruš zjistil, že pečet' musejní uzavírající nádobu a chovající zápis, že uvnitř uchován jest mozek F. Palackého, uvolnil pečet', načež nádoba byla otevřena. Mozek, vyňatý po smrti F. Palackého MUDrem J. Šteffalem, byl konservován i s dura [= pia] mater. Aby zjištěn byl stav konservace mozku samého, provedl pan prof. Janošík malý kř́žový řez a shlednáno, že mozek jest uvnitř nedostatečně fixován. Proto usneseno, aby mozek přeložen byl do větší nádoby a uložen v nové konservační tekutině a sice ve formalínu a glycerinu. Poté nádoba pečlivě uzavřena a prof. Jirušem musejní pečetí opatřena. // Tento nález sdělen panu Prof. MUDru J. Rohonovi, zároveň s výslovným přáním rodiny Palackého, dle něhož nesmí býti mozek pitván, a tedy se nesmí ani blány mozkové kterými ještě jest pokryt, odstraniti, a rovněž nesmí býti ničeho jiného podniknuto, čím by mozek mohl býti porušen. Po tomto sdělení pan Prof. Rohon od prozkoumání vůbec upustil. // Mozek zůstal tudíž nedotknutý v tom stavu, v jakém byl shora zmíněnou komisí uschován a zapečetěn. // Poněvadž podepsaný odchází 1. ledna 1930 [= 1931] do výslužby, odevzdává jemu svěřený mozek historiografa Fr. Palackého s vědomím a z nařízení jednatele společnosti musejní pana univ. prof. Dra K. Domina adm. řediteli Nár. Musea p. J. [= A.] Zemkovi ku prozatímnímu uschování v kanceláři musejní.

[podpis:] Dr V. Vávra

vrchní ředitel // zoologického a geologicko-paleontologického // oddělení Národního Musea v Praze II-1700.

RNM, karton 114, 1931/X/P1 [dopis, strojopis, 1 p] (obr. 8)

Zoologické oddělení Národního Musea // v Praze II-1700

V Praze, dne 27. února 1931.

K čj. 554 Nár. Mus. // ze dne 10. prosince 1930

Věc: Odevzdání mozku // historiografa // Fr. Palackého.

Přijímací list.

Správě Národního Musea // v Praze.

Z nařízení jednatele N. Musea pana Prof. K. Domina k shora uvedenému číslu jednacímu odevzdává podepsaný skleněný válec, $v$ němž uložen jest mozek historiografa Františka Palackého, uzavřený pečetí Národního Musea, panu adm. řediteli A. Zemkovi.

[podpis:] Dr V. Vávra

[razítko:] vrchní ředitel // zoologického a geol.-paleontolo- // gického odd. Národ. Musea v Praze.

[rukopis/podpis:] Vidi: // Dr K. Domin

[rukopis/podpis:] a.a. // Zemek

[rukopis/podpis:] Převzal jsem do uschování // a vydal jsem o tom $p$. vrch. // řed. Dr Vávrovi potvrzení. // Zemek 
BAS [bez archivní signatury] 1949/b. č. [= bez čísla] [dopis, strojopis na hlavičkovém dopisním papíře, $1 \mathrm{p}$ ]

ANATOMICKÝ ÚSTAV // KARLOVY UNIVERSITY

PRAHA II, U NEMOCNICE Č. 2 - TEL. 327-57

PŘEDNOSTA: Prof. L. Borovanský

Č.j.: 1233/49

Věc: Mozek Frant. Palackého // převzetí do úschovy.

Národní museum v Praze, // Praha II., Václavské nám. 68.

K Vašemu přípisu č.j. 5761/Ča ze dne 28. XII. 1949 oznamuje anatomický ústav, že jmenovaný preparát vrátí v měsíci lednu, poněvadž je nutno ne doplniti, nýbrž zcela vyměniti konservační kapalinu.

Dne 30. prosince 1949

[podpis:] Borovanský

přednosta anatom. ústavu

[kulaté razítko anatomického ústavu:] ANATOMICKÝ ÚSTAV // PRAHA

[rukopis:] Věd. styk domácí

[rukopis:] Vzato na vědomí // A.a. Wagner

[přijímací razítko Národního musea:] NÁRODNí MUSEUM V PRAZE // Číslo: 5810 // Došlo dne: 31. XII. 1949 // Počet př́loh:

BAS [bez archivní signatury] [protokol, strojopis doplňovaný rukopisnými poznámkami, 1 p] (obr. 9)

Mozek Františka Palackého

v konservační tekutině ve válcové nádobě uložené v dřevěné skř́ínce černě mořené // byl vložen do stěny Pantheonu v sousedství sochy Františka Palackého za přítomnosti

Dr Vladimíra Denksteina, ředitele Národního musea

Dr Karla Tučka, náměstka ředitele Národního musea a

Dr Zoroslavy Drobné, přednosty historicko-archeologického oddělení Národního musea dne 30. srpna 1958 v 10.15 hod.

záznamy o doplňování konservační tekutiny:

Datum Složení a množství doplněného // konservačního roztoku Podpis // provádějícího

\begin{tabular}{|c|c|c|}
\hline 2.9.59. & Shledáno v pořádku & Dr Štěpánek // Dr Denkstein \\
\hline 1961 & $-\ldots--$, & Dr Štěpánek \\
\hline $1964 / X I I$ & $-\ldots--$, & Dr Štěpánek \\
\hline $14 / 1 / 1970$ &,,$---_{-,}-$ & Dr Vlček \\
\hline $15 / 6 / 1976$ &,- & Dr Vlček \\
\hline $5 / 1 / 1993$ &,$- \ldots--$, & Dobisíková \\
\hline $16 / 7 / 2009$ &,$- \ldots--$ & Dobisíková \\
\hline
\end{tabular}




\section{APPENDIX 2}

\section{Zmiňované osoby}

Sestaveno dle údajů Štěpánka (1975), Tomeše \& Léblové (1992), Chalupy a kol. (1998), Sklenáře (2001, 2007), Šlechtové \& Levory (2004), Rosolové (2014), Woitschové \& Jůna (2019) a dalších veřejných zdrojů; na ty také odkazujeme v případě bližšího zájmu o dotyčnou osobu.

Behterev [Bechtěrev], Vladimir Mihajlovič (1857-1927), lékař, neurofysiolog a psychiatr; největší proslulosti doznal svým studiem paměti, reflexů a Bechtěrevovy nemoci;

Borovanský, Ladislav (1897-1971), lékař a anatom; v letech 1937-1939 a pak 1945-1970 přednostou anatomického ústavu lékařské fakulty, resp. fakulty všeobecného lékařství University Karlovy v Praze, v letech 1946-1947 děkanem lékařské fakulty UK;

Bráf, Albín (1851-1912), právník a staročeský politik; v letech 1908-1909 a 1911-1912 ministrem orby Království a zemí na říšské radě zastoupených (tj. předlitavské části Rakouska-Uherska), v letech 1893-1894 a 1902-1903 děkanem právnické fakulty české Karlo-Ferdinandovy university v Praze, kde byl od roku 1890 řádným profesorem národního hospodářství; od roku 1903 členem České akademie císaře Františka Josefa pro vědy, slovesnost a umění; zet' Františka Ladislava Riegera, manžel jeho dcery Libuše Riegrové (1860-1931);

Červinková-Riegrová, Marie (1854-1895), spisovatelka; vnučka Františka Palackého a dcera Františka Ladislava Riegera a Marie Riegrové-Palacké;

Denkstein, Vladimír (1906-1993), historik umění; v letech 1956-1970 ředitelem Národního musea, předtím (1946-1956) náměstkem ředitele NM, v letech 1946-1956 přednostou historicko-archeologického oddělení NM; v letech 1971-1973 presidentem Společnosti Národního musea;

Dobisíková, Miluše (*1943), fysická anthropoložka; vedoucí anthropologického oddělení Národního musea v letech 1991-2003;

Domin, Karel (1882-1953), botanik a politik; v letech 1933-1934 rektorem University Karlovy, v letech 1922-1923 děkanem př́rodovědecké fakulty této university, kde byl od roku 1916 profesorem botaniky; jednatelem Společnosti Národního musea, resp. Zemského musea v Praze, v letech 1921-1945; od roku 1924 členem České akademie věd a umění, roku 1918 založil časopis Věda Přírodní, v roce 1926 navrhl zřídit Tatranský národní park (zřízen 1949);

Drobná, Zoroslava (1907-1988), historička umění; v letech 1956-1959 přednosta historickoarcheologického oddělení Národního musea v Praze, v letech 1959-1960 přednosta numismatického oddělení NM;

Frič, Antonín (1832-1913), zoolog a paleontolog (vzděláním lékař); jedna z nejvýznamnějších osobností české prrírodovědy druhé poloviny 19. století a vzhledem k odborné šíri a produkci patrně dodnes nejvýznamnější přírodovědec profesně spojený s (dnešním) Národním museem; od roku 1852 byl neplaceným asistentem a od roku 1854 úředníkem, později kustodem zoologických sbírek Musea království Českého, v letech 1880-1913 ředitelem zoologických a paleontologických sbírek; v letech 1891-1892 byl rektorem české Karlo-Ferdinandovy university, v letech 1885-1886 děkanem filosofické fakulty téže university, kde byl od roku 1882 profesorem zoologie a geologie; od roku 1890 členem České akademie císaře Františka Josefa pro vědy, slovesnost a umění; v letech 1873-1907 byl vedoucím redaktorem časopisu Vesmír;

Gauss, Carl Friedrich (1777-1855), matematik a fysik; profesor astronomie a ředitel hvězdárny v Gotinkách;

von Habsburg-Lothringen, Ferdinand Karl Leopold Joseph Franz Marcellin (1793-1875), rakouský císař jako Ferdinand I., zvaný Dobrotivý (1835-1848); jako Ferdinand V. král uherský (1830) a poslední korunovaný král český (1836) a lombardsko-benátský (1838);

von Habsburg-Lothringen, Franz Karl Joseph (1802-1878), bratr rakouského císaře Ferdinanda I. a otec císaře Františka Josefa I.; 
von Habsburg-Lothringen, Otto [Franz Joseph Otto Robert Maria Anton Karl Max Heinrich Sixtus Xavier Felix Renatus Ludwig Gaetan Pius Ignatius] (1912-2011), politik, novinář a spisovatel; arcivévoda a poslední sloužící korunní princ Rakouska-Uherska, nejstarší syn posledního císaře Karla I. (formálně českého krále Karla V.);

Hanáková, Hana (*1933), fysická anthropoložka; nejprve zaměstnána v Archeologickém ústavu Československé akademie věd, v letech 1969-1990 v anthropologickém oddělení Národního musea, jehož byla během roku 1990 vedoucí;

Harrach, Jan Nepomuk František (1828-1909), velkostatkář, průmyslník, filantrop a politik; v letech 1890-1909 presidentem Společnosti Musea království Českého;

Henle, Friedrich Gustav Jakob (1809-1885), lékař a anatom; znám zejména díky objevu Henleho kličky v savčí ledvině; v letech 1840-1844 profesorem anatomie na Curyšské universitě, 1844-1852 na Ruprechtově-Karlově universitě v Heidelberku a od roku 1852 až do smrti na Universitě Jiř́ího Augusta v Gotinkách;

Hlava, Jaroslav (1855-1924), lékař a patholog; v letech 1906-1907 rektorem české KarloFerdinandovy university, v letech 1891-1892, 1897-1898, 1903-1904 a 1912-1913 děkanem lékařské fakulty této university, kde byl od roku 1887 profesorem pathologické anatomie; od roku 1894 členem České akademie císaře Františka Josefa pro vědy, slovesnost a umění; od roku 1918 president Státní zdravotní rady;

Hlávka, Josef (1831-1908), stavitel, politik a mecenáš; zakladatel a podporovatel České akademie císaře Františka Josefa pro vědy, slovesnost a umění (1890), v letech 18901908 jejím prvním presidentem, ve stejném období předsedou IV. třídy akademie;

Huleš, Josef (1812-1887), obchodník a politik; v letech 1873-1876 purkmistrem královského hlavního města Prahy;

Janošík, Jan (1856-1927), lékař, histolog a anatom; v letech 1911-1912 rektorem české Karlo-Ferdinandovy university, v letech 1898-1899, 1905-1906 a 1913-1914 děkanem lékařské fakulty této university, v letech 1894-1926 přednostou anatomického ústavu téže fakulty, kde byl od roku 1893 profesorem histologie a embryologie; od roku 1902 členem České akademie císaře Františka Josefa pro vědy, slovesnost a umění;

Jiruš, Bohuslav (1841-1901), lékař, farmakolog a botanik, dvorní rada (1896); od roku 1891 členem správního výboru Společnosti Musea království Českého, v letech 18971901 jednatel Společnosti Musea království Českého; v letech 1888-1889 a 1893-1894 děkanem lékařské fakulty české Karlo-Ferdinandovy university; v letech 1875-1886 profesorem botaniky na Universitě Františka Josefa I. v Záhřebu, pak profesorem farmakologie a farmakognosie na lékařské fakultě Karlo-Ferdinandovy university v Praze;

Kvapil, František (1855-1925), básník a překladatel; v letech 1893-1909 tajemníkem Musea království Českého, v letech 1909-1920 ředitelem kanceláře Musea království Českého; od roku 1923 členem České akademie věd a umění;

Lány, Karel Eduard (1838-1903), evangelický kněz; od roku 1864 farářem v Černilově, od roku 1902 superintendentem české superintendence augšpurského vyznání; roku 1870 založil a redigoval časopis Evengelický Církevník;

Marek, Antonín (1785-1877), kněz, básník, překladatel a jazykovědec; s Josefem Jungmannem spoluvytvářel a zaváděl dodnes používané české pojmosloví;

Molnár, Daniel Bohumil (1819-1889), evangelický kněz; 1843-1846 vikářem v Praze, 18461865 farářem v Krucemburku a pak rok v Humpolci, od roku 1866 v Praze; od roku 1874 superintendentem české superintendence augšpurského vyznání;

Myslbek, Josef Václav (1848-1922), sochař; profesor sochařství na Uměleckoprůmyslové škole v Praze (1885-1896), pak na Akademii výtvarných umění (1896-1919); od roku 1890 byl členem České akademie císaře Františka Josefa pro vědy, slovesnost a umění; sňal posmrtnou masku a vyhotovil odlitek ruky Františka Palackého a vytvořil jeho bustu, dnes umístěnou na domě, v němž sídlí Památník Františka Palackého a Františka Ladislava Riegera Národního musea v Palackého ulici v Praze;

Obenberger, Jan (1892-1964), zoolog (entomolog); od roku 1920 asistentem v zoologickém oddělení Národního musea v Praze, v letech 1933-1953 přednostou zoologického 
oddělení NM, 1953-1956 přednostou jím nově založeného entomologického oddělení NM; v letech 1956-1962 ředitelem jím založeného Entomologického ústavu Československé akademie věd v Praze;

Palacký, Jan (1830-1908), geograf a staročeský politik; první mimořádný (1885), resp. řádný (1891) profesor zeměpisu na filosofické fakultě české Karlo-Ferdinandovy university v Praze; syn Františka Palackého;

Patera, Adolf (1836-1912), filolog; v letech 1893-1904 knihovníkem Musea království Českého, v knihovně však pracoval od roku 1861, zaměstnán byl od roku 1863 jako asistent, od roku 1876 jako kustod; od roku 1900 členem České akademie císaře Františka Josefa pro vědy, slovesnost a umění;

Prokeš, Josef (1841-1927), lékař; v letech 1870-1906 asistentem okresního lékaře v Praze; od roku 1896 předsedou Spolku českých lékařů;

Rayman, Bohuslav (1852-1910), chemik; první mimořádný (1890), resp. řádný (1897) profesor organické chemie na filosofické fakultě české Karlo-Ferdinandovy university v Praze; od roku 1890 členem České akademie císaře Františka Josefa pro vědy, slovesnost a umění, v letech 1899-1910 byl jejím generálním sekretářem; roku 1891 obnovil a redigoval vydávání časopisu Živa;

Rejsek, Josef (1860-1932), malíŕ, ilustrátor a preparátor; v letech 1894-1926 preparátorem anatomického ústavu lékařské fakulty české Karlo-Ferdinandovy university v Praze; kromě zhotovování preparátů také ilustroval učebnice a odborné texty;

Retzius, Anders Adolph (1796-1860), lékař a anatom; volený člen Královské švédské akademie věd; objevitel Retzova prostoru sousedícího s dutinou břišní a Retzových (Retziusových) proužků v zubní sklovině;

Rieger, František Ladislav (1818-1903), publicista a staročeský politik; spoluzakladatel a druhý předseda Národní strany (staročeské), patrně nejvýznamnější osobnost českého politického života druhé poloviny 19. století; zet' Františka Palackého, manžel jeho dcery Marie Riegrové-Palacké (1833-1891);

Rohon, Josef Viktor / Rohonyi, Josef Victor (1845-1923), paleontolog a neuroanatom; v letech 1909-1910 děkanem lékařské fakulty české Karlo-Ferdinandovy university v Praze, v letech 1895-1915 přednostou histologicko-embryologického ústavu téže fakulty;

Skalský Gustav (1891-1956), historik (numismatik); v letech 1946-1956 ředitelem Národního musea;

Skramlík, Emilián František (1834-1903), podnikatel a politik; v letech 1876-1882 purkmistrem královského hlavního města Prahy;

Skrejšovský, Jan Stanislav (1831-1883), novinář a staročeský politik; roku 1862 založil a pak redigoval list Politik, později také časopis Brousek;

Šteffal / Steffal, Václav (1841-1894), lékař a anatom; v letech 1872-1883 městský okresní lékař v Praze, později (první) přednosta anatomického ústavu lékařské fakulty české Karlo-Ferdinandovy university v Praze (1883-1894);

Štěpánek, Otakar (1903-1995), zoolog (především herpetolog); v letech 1964-1965 prvním ředitelem Př́rodovědeckého musea Národního musea v Praze, v letech 1923-1955 postupně volontérem, asistentem, úředníkem, zástupcem přednosty, a v letech 19551966 přednostou zoologického oddělení NM; v několikaměsíčním období kolem přelomu let 1948-1949 ředitelem zoologické zahrady v Praze;

Tomek, Wácslaw Wladiwoj / Václav Vladivoj (1818-1905), archivář a historik, staročeský politik; vládní rada, v letech 1882-1883 (prvním) a pak v letech 1885-1886 opět rektorem české Karlo-Ferdinandovy university, kde byl od roku 1860 profesorem rakouských dějin; od roku 1890 byl členem České akademie císaře Františka Josefa pro vědy, slovesnost a umění; vicepresidentem Společnosti Musea království Českého v letech 1877-1905, jednatelem Společnosti Musea království Českého v letech 1852-1877; v letech 18391848 byl vychovatelem Palackého dětí Jana a Marie;

Třeštík, Dušan (1933-2007), historik a publicista; od roku 1958 do konce života působil v Historickém ústavu Československé akademie věd, resp. Akademie věd České republiky; 
Tuček, Karel (1906-1990), mineralog; v letech 1939-1950 a pak 1956-1976 přednostou mineralogického, resp. mineralogicko-petrografického oddělení Národního musea; v letech 1950-1951 byl přednostou Náprstkova musea, v letech 1951-1953 byl ředitelem Národního technického musea a v letech 1953-1956 přednostou odboru museí na ministerstvu školství a osvěty, resp. ministerstvu kultury Československé republiky; jednatelem Společnosti Národního musea v letech 1945-1969;

Vávra, Václav (1866-1941), zoolog; 1887-1894 asistentem zoologie na české KarloFerdinandově universitě, od roku 1894 adjunktem a 1907 kustodem zoologických a paleontologických sbírek Musea království Českého, roku 1913 pověřen vedením a v letech 1916-1930 ředitelem zoologických sbírek, od roku 1923 také ředitelem sbírek geologických; od roku 1909 byl členem České akademie císaře Františka Josefa pro vědy, slovesnost a umění;

Vlček, Emanuel (1925-2006), lékař a fysický anthropolog; v letech 1945-1957 anthropologem Archeologického ústavu Slovenské akademie věd v Nitře, v letech 1957-1967 Archeologického ústavu Československé akademie věd v Praze; v roce 1967 založil anthropologické oddělení Národního musea, jehož byl vedoucím do roku 1974, v letech 1977-1991 byl vedoucím referátu pro anthropologický výzkum historických osobností a vývoje člověka Národního musea;

Vrtátko, Antonín Jaroslav (1815-1892), spisovatel a překladatel; v letech 1861-1892 bibliothekář Musea království Českého, přímý nástupce prvního bibliothekáře Václava Hanky (1791-1861); od roku 1890 členem České akademie císaře Františka Josefa pro vědy, slovesnost a umění; v letech 1861-1864 redaktorem Časopisu Musea království Českého;

Wagner, Rudolf Friedrich Johann Heinrich (1805-1864), lékař; anatom, zoolog a fysiolog; v letech 1832-1840 profesorem zoologie a srovnávací anatomie University v Erlangenu, od roku 1840 profesorem zoologie, fysiologie a srovnávací anatomie na Universitě Jiř́ího Augusta v Gotinkách a od roku 1844 prorektorem téže university;

Weiss, Vilém / Wilhelm (1835-1891), lékař; v letech 1887-1888 rektorem české KarloFerdinandovy university, v letech 1883-1886 prvním děkanem lékařské fakulty téže university; od roku 1876 byl primářem dětské nemocnice Františka Josefa a od roku 1882 primar-chirurgem Všeobecné nemocnice;

Zeithammer, Antonín Otakar (1832-1919), staročeský politik; poslancem ve více zastupitelských sborech, včetně Říšské rady (1879-1891); v letech 1873-1879 náměstek purkmistra královského hlavního města Prahy, v době pohřbu Františka Palackého formálně předsedou městské rady vzhledem k pražskému interregnu;

Zemek, Antonín (1892-[1955]), úředník; 1928-1931 administrativním úředníkem, v letech 1931-1946 administrativním ředitelem, resp. ředitelem Národního musea, resp. Zemského musea v Praze, v letech 1937-1941 i správcem knihovny NM/ZM.

\section{Summary}

František Palacký (1798-1876) is considered the most influential representive of ethnical emancipation of the Czech nation during the 19th century, a historian and politician, already during his life called a Father of the Nation. He died on 26 May 1876 in Prague and his funeral was an important event for the Czech society; the Palacký's corpse was put on display to the public for three days, when thousands of people visited it to pay tribute to his personality. On 
30 May 1876, in the evening before the burial, the Palacký's head was dissected and his brain was extracted and stored as a museum preparation in the solution of the mercuric chloride. According to the published data, the brain was very soon deposited in the Museum of the Kingdom of Bohemia (present National Museum) in Prague. While the current fate of the Palacký's brain is known, it is stored in a cylindrical jar and wooden box concealed in a wall niche (Figs. 1 and 2) of a column (next to a large statue of Palacký) in the Pantheon hall of the historical building of the National Museum on the Wenceslaus square in Prague, the history of this preparation has not been clear. The investigation of the Museum archive brought some documents which indicate several crucial events in the brain's history, although its whereabouts during some periods still remain unclear.

The first note is a letter (Fig. 4) from 10 December 1878 written by the Museum librarian Antonín Jaroslav Vrtátko (1815-1892), who stressed an inopportune situation of the brain preparation, stored in a jar deposited in the Museum library. Another series of documents come from the period between October 1899 and June 1900 (Figs. 5-7). They evidence the request by Josef Victor Rohon (1845-1923), a professor of neuroanatomy at the CharlesFerdinand University of Prague, to investigate the structure of the Palacký's brain, and the Museum's response, finishing in a commissional inspection of the inner tissue of the brain and its new conservation (without any investigation by Rohon, eventually). These documents indicate that the brain was kept by Antonín Frič (1832-1913), the then curator of zoological and palaeontological collections of the Museum, most probably from a certain time in the period between 1878 and 1892 (but for sure before 1899). In June 1900, it was transferred to the personal care of Václav Vávra (1866-1941), then an assistant of zoology at the Museum. Several other documents come from 1930-1931, when Vávra, then a curator of zoological and palaeontological collections, preparing himself for retirement, transferred the brain to the care of Antonín Zemek (1892-[1955]), an administrative director of the Museum (Fig. 8).

Next fate of the brain preparation is uncertain until 1958, when it was installed in the wall niche in the Pantheon hall, where it remains till now, with an interruption in the period 2015-2021 when the historical building of the Museum was under reconstruction. The evidence shows that in the period [1878-]1899-1931 and again after 1958, the Palacký's brain preparation was under responsibility of the Department of Zoology of the Museum and then, of the Department of Anthropology from 1967, when the latter division of the Museum was established.

Several facts remain noteworthy in this story; although in a certain sense the preparation of the Palacký's brain represents a direct symbol of the history of the emancipation struggle of the Czech nation, both in definite and abstract views of it, and thus, it is a rather spiritual reminder, it was always (according to the available evidence) under responsibility of the natural history departments of the Museum. However, this is well understandable due to the biological nature of the preparation. On the other hand, although the brain was under responsibility of the natural history departments, it was never accepted as a mere biological preparation, besides the proper action of its conservation. Albeit the brain was extracted from the Palacký's body for the purpose of investigation of the Palacký's brilliance, i.e. the investigation with help of morphological approaches, it was never investigated. The only available simple description of the Palacký's brain originates from the report of the Palackýs autopsy published by Šteffal (1877), the then district physician of Prague. The detailed histological investigation of the brain tissue, that was declared as a reason for the keeping of the brain preparation in the period immediately after Palacký's death, was made neither by Šteffal nor Rohon nor any other researcher. Thus the preparation remains kept as a commemorative part of the body of the Father of the Nation in the Pantheon and the National Museum building represents just a detached unit of Palacký's tomb at the cemetery of Lobkovice (a village north of Prague), where the other remains of the Palacký's corpse rest in peace. 